\title{
The Echoes of Slavery: Recognizing the Racist Origins of the Agricultural and Domestic Worker Exclusion from the National Labor Relations Act
}

\author{
JuAN F. PereA* \\ TABLE OF CONTENTS
}

I. The Social AND Political ConteXt of THE NEW DEAL ............. 100

A. Blacks and Southern Agriculture ........................................ 100

B. The Politics of the New Deal .................................................. 102

II. THE EXCLUSION OF BLACKS FROM THE NEW DEAL ....................... 104

A. The National Industrial Recovery Act (1933) ....................... 104

B. Agricultural Adjustment Administration (1933) ..................... 107

C. The Social Security Act (1935) .............................................. 109

D. The Fair Labor Standards Act (1938)..................................... 114

III. THE NATIONAL LABOR RELATIONS ACT AND ITS EXCLUSION OF AGRICULTURAL AND DOMESTIC EMPLOYEES ............................. 118

A. The Legislative History of Section 152(3).............................. 118

B. Interpreting Section 152(3) of the NLRA as Racially

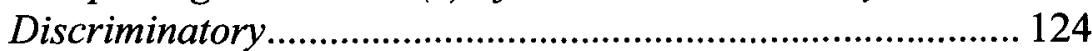

IV. THE AGRICULTURAL AND DOMESTIC WORKER EXCLUSION

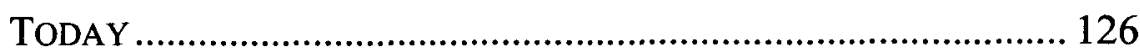

A. Litigation Strategy................................................................ 127

1. Proof of Discriminatory Intent .......................................... 129

2. The Difference in Demographics ..................................... 133

* Cone, Wagner, Nugent, Johnson, Hazouri \& Roth Professor of Law, University of Florida Levin College of Law. Visiting Professor of Law, Loyola University Chicago School of Law, Fall 2010; Distinguished Visiting Reuschlein Professor, Villanova Law School, Spring, 2011. Thanks to Sam Brunson, Elizabeth Dale, Risa Goluboff, Leonard Mandell, John Nowak, Jennifer Rosato, Larry Schlam, D. Daniel Sokol, Christopher Slobogin, Barry Sullivan, Alexander Tsesis, Spencer Waller, and Mike Zimmer for their comments and suggestions. Thanks also to the faculties of University of Florida College of Law, Seton Hall Law School, University of Richmond Law School, Wake Forest Law School, University of Nevada at Las Vegas Law School, Washington College of Law at Catholic University, University of San Francisco College of Law, Northern Illinois University School of Law, and Loyola University Chicago School of Law for opportunities to present this work and for helpful questions and comments. I appreciate the generous financial support of the University of Florida Levin College of Law which enabled my work on this project. 


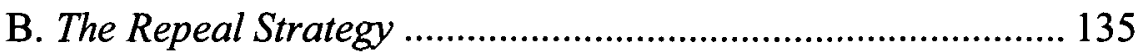

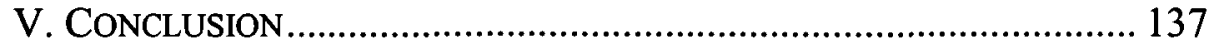

During the New Deal Era, the statutory exclusion of agricultural and domestic employees was well-understood as a race-neutral proxy for excluding blacks from statutory benefits and protections made available to most whites. ${ }^{1}$ Remarkably, despite these racist origins, an agricultural and domestic worker exclusion remains on the books today, entirely unaltered after seventy-five years. Section 152(3) of the National Labor Relations Act still excludes agricultural and domestic workers from the protections available under the Act. ${ }^{2}$

${ }^{1}$ Most historians agree that the exclusion of agricultural and domestic employees in the National Labor Relations Act should be understood as part of the pattern of racist exclusions enacted in the major New Deal Era statutes. See, e.g., PAUL FRYMER, BLACK AND BluE: AFrican AMERICANS, THE LABOR MOVEMENT, AND THE DECline OF THE DEMOCRATIC PARTY 27-28 (2008) ("The presence of Southern Democrats and their willingness to stray from the party line to block civil rights legislation not only prevented such legislation but necessitated that economic bills include provisions that either explicitly or, more often simply in a de facto manner, discriminated against large numbers of minority workers. The common method of this was for legislators to exclude categories of workers where African American and other minorities predominated, such as domestic and agricultural workers."); RISA L. GOLUBOFF, THE LOST PROMISE OF CIVIL RIGHTS 29 (2007) ("Like many of the New Deal's economic protections, [the NLRA] excluded agricultural and domestic workers. Many of those workers were African American, so their exclusion marked a concession to southern white congressmen."); IRA KATZNELSON, WHEN AFFIRMATIVE ACTION WAS WhiTE 59 (2005) ("It is not hard to see why southern members were so intensely concerned with [the agricultural exclusion] ... The status of subaltern black labor in agriculture-a structure that often came close to resembling nineteenth-century conditions under slavery-was a consistent concern for southern members in the 1930s . ..."); HARVARD SITKOFF, A NEW DEAL FOR BLACKS 52 (1978) ("Nor could Wagner do much to protect Afro-Americans from being excluded from the labor union movement.... The civil rights groups pressing for the antidiscrimination amendment could not match the influence of those opposed to it.").

Some scholars have reached different conclusions. Marc Linder, while concluding that "New Deal legislation, including the FLSA [Fair Labor Standards Act], became infected with unconstitutional racial motivation," also commented that "[t]he one possible exception to this was the exclusion of agricultural employees from the National Labor Relations Act." Marc Linder, Farm Workers and the Fair Labor Standards Act: Racial Discrimination in the New Deal, 65 TEX. L. REV. 1335, 1336 \& n.12 (1987). Two scholars claim that the exclusion was an "anomaly," "not the product of a deliberate policy." See Michael H. LeRoy \& Wallace Hendricks, Should "Agricultural Laborers" Continue to Be Excluded from the National Labor Relations Act?, 48 EMORY L.J. 489, 490-91 (1999). I think LeRoy and Hendricks are wrong. As I demonstrate in this Article, the exclusion was no anomaly; it resulted from a deliberate, though unstated, policy of accommodating southern racism.

229 U.S.C. $\$ 152(3)$ provides, "The term 'employee' shall include any employee . . but shall not include any individual employed as an agricultural laborer, or in the 
Between two and three million agricultural workers, ${ }^{3}$ and an unknown but large number of domestic workers, ${ }^{4}$ are denied federally-protected rights to bargain collectively because of the exclusion. Most of these workers live a grinding poverty unimaginable to most readers. Seventy-five percent of farm laborers earn less than $\$ 10,000$ per year, 5 and their median income is $\$ 7,500$ or less per year. ${ }^{6}$ Farm workers have been described aptly as "among the most exploited groups in the American labor force."7 Domestic workers, too, have been described as "among the most vulnerable workers in our society." 8 Contemporary farm workers endure substandard wages, often brutal working conditions, no health insurance or other employee benefits, horrifying living conditions, and environmental hazards. ${ }^{9}$ Contemporary domestic workers also endure low wages and sometimes brutal working conditions, along with harassment, and psychological and sexual abuse. ${ }^{10}$ Many farm and domestic workers are modern-day slaves, a characterization borne out by numerous and recent successful federal prosecutions for involuntary servitude, i.e., slavery, occurring within these occupations. ${ }^{11}$ Indeed, one court has written

domestic service of any family or person at his home ...." (emphasis added).

3 The HuMAN COST of FoOd: Farmworkers' Lives, LABOR, AND ADVOCACY 3 (Charles D. Thompson, Jr. \& Melinda F. Wiggins eds., 2002) [hereinafter HUMAN COST OF FOOD].

${ }^{4}$ Because many domestic workers are undocumented immigrant women, it is very difficult even to approximate a number. The number is certainly in the millions, gauging from what can be known. In 1989, between 250,000 and 450,000 undocumented domestic workers were estimated to work in New York City alone. See Peggie R. Smith, Regulating Paid Household Work: Class, Gender, Race and Agendas of Reform, 48 AM. U.L. REV. 851, 923 n.437 (1999). A more recent estimate described 200,000 domestic workers in New York State. See Statistics on Domestic Workers in New York State, DOMESTIC WORKERS UNITED, http://www.domesticworkersunited.org/media.php?show $=69$ (last visited Jan. 6, 2011).

${ }^{5}$ HuMAN COST OF FoOd, supra note 3, at 7.

6 JOHN BOWE, NOBODIES: MODERN AMERICAN SLAVE LABOR AND THE DARK SIDE OF THE NEW Global ECONOMY 8 (2007); ERIC SCHLOSSER, REEFER MADNESS: SEX, DRUGS AND CHEAP LABOR IN THE AMERICAN BLACK MARKET 79 (2003).

${ }^{7}$ Caro-Galvan v. Curtis Richardson, Inc., 993 F.2d 1500, 1505 (11th Cir. 1993) (quoting S. REP. No. 93-1295, at 1-3 (1974)).

${ }^{8}$ Nancy Zarate Byrd, The Dirty Side of Domestic Work: An Underground Economy and the Exploitation of Undocumented Workers, 3 DEPAUL J. FOR SOC. JUST. 245, 246 (2010).

${ }^{9}$ See Bowe, supra note 6 , at 8-9, 13, 36 .

${ }^{10}$ Many writers have documented the economic, sexual, and psychological abuse, sometimes constituting indentured servitude, faced by domestic workers. See, e.g., Byrd, supra note 8, at 245-47 \& n.4; Kristi L. Graunke, "Just Like One of the Family": Domestic Violence Paradigms and Combating On-The-Job Violence Against Household Workers in the United States, 9 MICH. J. GENDER \& L. 131, 132-33 (2002).

11 For convictions of farm workers for involuntary servitude, see, for example, 
that "[m]ost peonage and involuntary servitude cases in recent years have involved migrant agricultural workers." 12

There is a direct relationship between this modern slavery and contemporary labor law. Advocates for migrant farm workers express that relationship: "Modern-day slavery cases don't happen in a vacuum. They only occur in degraded labor environments, ones that are fundamentally, systematically exploitive. In industries where the labor force is conti[n]gent, day-haul, with subpoverty wages, no benefits, no right to overtime, no right to organize - that's where you see slavery taking root."13 Slavery does not exist in labor environments that offer adequate worker protections like collective bargaining and other federally protected rights. A huge disparity exists between the exploitation and vulnerability lived by agricultural and domestic workers and the more reasonable and humane labor conditions existing in most other occupations.

As I will show, the exploitation and vulnerability faced by these workers is no accident. The New Deal Congress desired and produced exactly this result. Specifically, southern congressmen wanted to exclude black employees from the New Deal to preserve the quasi-plantation style of agriculture that pervaded the still-segregated Jim Crow South. ${ }^{14}$ While they supported reforms that would bring more prosperity to their relatively poor region, they rejected those that might upset the existing system of racial segregation and exploitation of blacks. President Roosevelt and his legislative allies recognized that in order to pass any New Deal legislation at all, it was necessary to compromise with Southern Democrats intent on

United States v. Ramos, 130 Fed. Appx. 415, 419 (11th Cir. 2005) (labor contractors in Florida held hundreds of migrant workers in involuntary servitude under threat of death); United States v. Flores, No. 98-4178, 1999 WL 982041, at *1-2 (4th Cir. Oct. 29, 1999) (labor contractor in South Carolina held workers in involuntary servitude under threat of death while brandishing and discharging firearms). For convictions for involuntary servitude of domestic workers, see, for example, United States v. Sabhnani, 599 F.3d 215, 225-30 (2d Cir. 2010) (married couple held domestic servants in servitude by withholding passports, actual and threatened violence, and degrading treatment); United States v. Alzanki, 54 F.3d 994, 998-99 (1st Cir. 1995) (upholding conviction for holding domestic servant in involuntary servitude by threatening death, or serious bodily harm and deportation, committing assault, confiscating passport, denying access to outside world, and withholding medical attention and nutrition).

12 See Alzanki, 54 F.3d at 1000 n.3.

13 Bowe, supra note 6, at 36 (quoting Laura Germino, co-director of the Coalition of Immokalee Workers).

${ }^{14}$ Sean Farhang \& Ira Katznelson, The Southern Imposition: Congress and Labor in the New Deal and Fair Deal, 19 STUD. AMER. POL. Dev. 1, 6, 12-13 (2005); Ira Katznelson, Kim Geiger \& Daniel Kryder, Limiting Liberalism: The Southern Veto in Congress, 1933-1950, 108 POL. SCI. Q. 283, 290, 292-93, 296 (1993). 
preserving white supremacy. ${ }^{15}$ The compromise position was race-neutral language that both accommodated the southern desire to exclude blacks but did not alienate northern liberals nor blacks in the way that an explicit racial exclusion would. An occupational classification like agricultural and domestic employees, excluding most blacks without saying so, was just such race-neutral language.

In this Article, I show why Section 152(3) of the National Labor Relations Act should be considered a racially discriminatory statute motivated by racial animus. I examine the evidence surrounding the enactment of Section 152(3) and conclude that the statute was motivated by racially discriminatory intent. Remarkably, Section 152(3) remains federal law and, to date, its validity has not been questioned seriously.

This Article addresses the numerous questions that arise when a manifestly racist law, couched in race-neutral language that has raciallytargeted effects, remains federal law with unquestioned legitimacy. The continued existence of this law provides an example of how structural racism is produced and perpetuated through the intentional deployment of raceneutral language. Beyond the unseemly symbolism of a racist-yet-valid law remaining from the New Deal Era, this law continues to cause injury through its devastating impact upon the most vulnerable workers in our society. It is crucial that this law be recognized as racist and unjust to provide a rationale for its abolition and to remedy, finally, the ongoing injury it continues to cause.

Having established that the statute is racially discriminatory, this Article makes the case for why Section 152(3) should be considered unconstitutional or be repealed. While the historical evidence permits us to strip away the law's neutral aura, this Article demonstrates how current constitutional standards make the invalidation of such a law difficult. Current constitutional standards thus perpetuate structural racism by making it difficult to prove that a racially discriminatory law violates the Equal Protection Clause. ${ }^{16}$

15 KATZNELSON, supra note 1 , at 55-61; cf. MiCHAEL J. KLARMAN, UNFINISHED BuSINESS: RACIAL EQUALITY IN AMERICAN HISTORY 116-17 (2007) (noting that President Roosevelt continued to oppose civil rights legislation despite AfricanAmericans' general enthusiasm for the New Deal and their personal regard for President Roosevelt).

16 The difficulty in proving discriminatory intent under the Constitution has generated important recent scholarship. See, e.g., Mario L. Barnes, Erwin Chemerinsky, \& Trina Jones, A Post-race Equal Protection?, 98 GEO. L.J. 967, 994 (2010) ("This treatment of constitutional claims ... presumes that disparate outcomes are no longer caused by racism. It is, in short, another attack on the salience of race."); Kevin R. Johnson, How Racial Profiling in America Became the Law of the Land: United States v. Brignoni-Ponce and Whren v. United States and the Need for Truly Rebellious Lawyering, 98 GEO. L.J. 1005, 1069 (2010) ("Put simply, the Equal Protection Clause, with its difficult problems of proof, has not proven to be a viable method for criminal 
The Article proceeds in several parts. Part I describes briefly the poverty and racism faced by blacks during the Depression Era, and how the politics of the Era led to the exclusion of most blacks from New Deal legislation. Part II describes several major New Deal Era statutes and the systematic, intentional exclusion of black employees from the statutes' federal protections. By the time the Social Security Act was passed in 1935, Congress had crafted explicit statutory exclusions of agricultural and domestic laborers as a proxy to exclude most black employees. Part III shows why Section 152(3) of the National Labor Relations Act should be considered a part of the pattern of racist exclusions of blacks by proxy that occurred in all the other major New Deal statutes. Part IV explores the difficulties of challenging the statute under current constitutional standards, which require proof of discriminatory intent. While these difficulties are not insurmountable, they raise the troubling possibility that a manifestly racist statute might not be found unconstitutional. To ensure that such racism is not perpetuated, I also explore a strategy favoring legislative repeal.

\section{The Social and Political ConteXt of THE NEW DEAL}

\section{A. Blacks and Southern Agriculture}

To understand why the exclusion of agricultural and domestic employees is racist requires some background information about the New Deal Era. Black Americans during the Depression were "the most disadvantaged major group in American society" and politically vulnerable due to their disenfranchisement and lack of representation. ${ }^{17}$ The black population in 1930 was predominantly southern, rural, and impoverished. ${ }^{18}$ Over half of the blacks living in the United States in 1930 lived in the South. ${ }^{19}$ Black employment in the South was disproportionately concentrated in unskilled agricultural and domestic labor. ${ }^{20}$

Since the time of slavery and up to the New Deal, plantation agriculture had been the most important feature of the southern economy and society.

defendants to address systemic reliance on race by local police."); Girardeau A. Spann, Disparate Impact, 98 GEO. L.J. 1133, 1143 (2010) ("Post-racial discrimination disadvantages racial minorities by refusing to recognize disparate impact as a cognizable form of racial inequality.").

17 See Raymond Wolters, The New Deal and the Negro, in 1 THE NEW DEAL: THE NATiONAL LeVEl 170 (John Braeman, Robert H. Bremner, David Brody eds., 1975); SITKOFF, supra note 1, at 34-35 (describing the Depression's heavy toll on black Americans).

18 SITKOFF, supra note 1 , at 35 .

$19 \mathrm{Id}$.

20 Id. at 37. 
Just as the antebellum southern plantation system depended on the forced labor of black slaves, so postbellum southern agriculture depended on exploitation and subordination of black labor. The formal abolition of slavery in the Constitution made little difference. One writer described the situation in 1936: "Slavery was too integral a part of the social life of the South and too vital to the interests of certain classes to be suddenly eliminated by a mere constitutional amendment. [It was necessary to find] new ways of perpetuating the Negro's enslavement."21 Agriculture, and the exploitation of black labor to support it, remained particularly and uniquely important to the South during the New Deal Era. ${ }^{22}$

Southern landowners developed many ways to keep black farm laborers under their control through economic duress and violence. The primary technique was the tenancy system, which involved, typically, blacks living and farming on land owned by a white farmer and paying the owner rent. ${ }^{23}$ White landowners kept black tenant farmers and wage laborers economically subservient by keeping them in a constant state of debt. ${ }^{24}$ Farm owners furnished their impoverished black farm workers with necessary supplies, including seed, fertilizer, and tools from plantation stores on credit. ${ }^{25} \mathrm{By}$ inflating the prices of supplies and charging exorbitant interest rates on loans, farm owners guaranteed that their tenants were permanently in debt to them. ${ }^{26}$ Backed by threats of violence and recapture, landlords required their tenants to pay off such debts before they could leave the farm. ${ }^{27}$ Such debt peonage continued despite repeated Supreme Court decisions declaring the practice unconstitutional. ${ }^{28}$ In addition, landowners kept black farm workers economically dependent through other practices such as stealing or failing to pay for their crops, evicting the tenants, stealing their furniture and means of transportation, and other illicit means. ${ }^{29}$

21 Pete Daniel, The Shadow OF Slavery: PeONage IN THE SOUTH, 1901-1969, at 174 (1990) (quoting Editorial, Slavery Seventy Years After, CHRISTIAN CENTURY, Dec. 9, 1936, at 53)); see also GOLUBOFF, supra note 1, at 57.

22 Linder, supra note 1, at 1343 ("Agriculture was largely a southern industry and the South was the only region of the country with a predominantly agricultural economy.").

23 GolUBOFF, supra note 1 , at 59 .

24 Id.

${ }^{25} \mathrm{Id}$.

${ }^{26}$ Id. at $59-64$.

${ }^{27} \mathrm{Id}$.

28 DANIEL, supra note 21 , at 170-92 (describing continued debt peonage and slavery in the South during the 1930s despite being declared unconstitutional).

${ }^{29}$ Black tenants and wage workers had no recourse. Indeed, "the legal system as a whole and the specific laws it enforced buttressed the power of individual white planters rather than provide redress for African Americans." GoLUBOFF, supra note 1, at 66. 


\section{B. The Politics of the New Deal}

The southern political economy, therefore, depended on the economic and social subordination of blacks through exploitation, violence, and segregation. ${ }^{30}$ Southern Democrats in Congress were unified in their desire to uphold segregation and to resist any threats to the Jim Crow South. ${ }^{31}$ They voted as a bloc to uphold the racist values of their region. ${ }^{32}$

There were two principal threats to the racially segregated southern political economy. First, initiatives that improved the economic welfare of blacks relative to whites threatened to reduce the economic dependence and subordination of blacks. ${ }^{33}$ Such initiatives included benefit payments or unemployment insurance under the Social Security Act, ${ }^{34}$ equal and minimum wages under the Fair Labor Standards Act, ${ }^{35}$ or equalized bargaining power under the National Labor Relations Act. ${ }^{36}$ Second, centralized federal administration of any such programs, rather than local administration, threatened to disrupt the racist status quo of exploitation and inequality for blacks. ${ }^{37}$

During the New Deal Era, Southern Democrats dominated Congress. ${ }^{38}$ "Throughout the [1930s], the representatives of Dixie remained entrenched in the most powerful seats in Congress. Southerners controlled over half the committee chairmanships and a majority of leadership positions in every New Deal Congress." ${ }^{39}$ Because Southern Democrats held the balance of

30 KLARMAN, supra note 15 , at $75-80$.

31 KATZnelson, supra note 1, at 19; RoBert C. LIEBERMAN, SHIFTING THE COLOR LINE: RACE AND THE AMERICAN WELFARE STATE 24 (1998).

32 LIEBERMAN, supra note 31 , at 28 ("Southern members did coalesce reliably on issues of perceived federal intervention, especially those affecting race and labor relations, matters that social security legislation profoundly touched.").

${ }^{33}$ Id. at 27 " "To the extent that a program such as Roosevelt sought provided universal social benefits, it threatened the political economy of the South, which was based on the utter economic dependence of mostly black agricultural labor. Any welfare policy that gave Southern farm workers sources of income independent of the planter elite and the political institutions that it dominated had the potential to undermine the rigid racial and class structures of the South.").

${ }^{34}$ Social Security Act of 1935, ch. 531, 49 Stat. 620 (codified in scattered sections of 42 U.S.C.).

35 Fair Labor Standards Act of 1938, 29 U.S.C. $\$ \S 201-219$ (2006).

${ }^{36}$ National Labor Relations Act of 1935, 29 U.S.C. $\$ \S 151-169$ (2006).

${ }^{37}$ LIEBERMAN, supra note 31, at 29-30, 37.

38 Id. at 28; SITKOFF, supra note 1 , at 45.

${ }^{39}$ SITKOFF, supra note 1 , at 45 . This degree of control resulted from a combination of congressional seniority rules, which determined access to influential positions, a tradition of one-party Democratic allegiance in the South, and the weakness of the Democratic Party outside the South. Id. 
power, Congress and President Roosevelt had to acquiesce in their demands to ensure the passage of legislation.

President Roosevelt simply would not embrace civil rights or egalitarian measures because they endangered the coalition necessary to enact his legislative agenda. ${ }^{40}$ Roosevelt's highest priority was enacting remedial legislation for most Americans, even if it meant excluding blacks and rejecting civil rights measures. ${ }^{41}$ According to Roosevelt, "First things come first, and I can't alienate certain votes I need for measures that are more important at the moment by pushing any measures that would entail a fight." 42 Responding to the problems created for blacks by lower wages under the National Recovery Act, Roosevelt commented that "[i]t is not the purpose of this Administration to impair Southern industry by refusing to recognize traditional differentials." 43 Explaining his failure to support antilynching legislation, Roosevelt said:

I did not choose the tools with which I must work.... Had I been permitted to choose them I would have selected quite different ones. But I've got to get legislation passed by Congress to save America. The Southerners by reason of the seniority rule in Congress are chairman or occupy strategic places on most of the Senate and House committees. If I come out for the anti-lynching bill now, they will block every bill I ask Congress to pass to keep America from collapsing. I just can't take that risk. ${ }^{44}$

There can be no clearer example of Roosevelt's willingness to sacrifice fundamental humanitarian and equality interests of blacks than his failure to support anti-lynching legislation. Members of the President's Administration, like Roosevelt, also accommodated racist southern desires. ${ }^{45}$

In the eyes of congressional and presidential decisionmakers, then, the politics of the Era required the exclusion of blacks from the New Deal. Only by excluding blacks could Southern Democrats both gain federal benefits for their impoverished region and preserve the racist status quo in the South. Only through race-neutral language could Northern Liberals countenance excluding blacks without directly alienating black political support. Since most southern blacks were employed as agricultural and domestic laborers,

40 Id. at 44.

$41 \mathrm{Id}$.

$42 I d$.

43 Raymond Wolters, Negroes and the Great DePression: The Problem OF ECONOMIC RECOVERY 145 (1970).

44 SitKoff, supra note 1, at 46 (quoting Walter White, A MAN Called White 169-70 (1948)).

45 Id. at 43-44; WOLTERS, supra note 43 , at 56-57. 
that occupational classification became an ostensibly race-neutral way to exclude blacks by proxy.

\section{THE EXCLUSION OF BLACKS FROM THE NEW DEAL}

Racism ran rampant against blacks during the New Deal. The following sections show how Congress accommodated and preserved this racism through the systematic, intentional exclusion of blacks from all the major enactments of the New Deal. These enactments include the National Industrial Recovery Act, ${ }^{46}$ the Agricultural Adjustment Act, ${ }^{47}$ the Social Security Act, ${ }^{48}$ and the Fair Labor Standards Act. ${ }^{49}$ Congress excluded blacks by proxy through occupational exclusions and by allowing southerners to discriminate against blacks through local, rather than federal, administration of benefits. By excluding agricultural and domestic workers, and therefore most southern black employees, from federal protections, southern representatives guaranteed that the New Deal posed little or no threat to the Jim Crow South.

\section{A. The National Industrial Recovery Act (1933)}

The racism permeating the National Industrial Recovery Act (NIRA) is apparent in the collective intention of its administrators and industry employers, particularly in the South, to deny equal wages to blacks. The NIRA called for codes of fair competition that fixed minimum wages and maximum hours in different industries. ${ }^{51}$ The National Recovery Administration (NRA), in turn, conducted hearings to gather evidence in formulating these codes for each industry. ${ }^{52}$ Racism is apparent in debates, occurring during the NRA code hearings, over whether the NRA should adopt an explicit racial differential allowing black workers to be paid less than whites. ${ }^{53}$ Although the racial differential was not adopted, the NRA developed ostensibly race-neutral means-occupational and geographic

46 National Industrial Recovery Act, ch. 90, 48 Stat. 195 (2006).

47 Agricultural Adjustment Act of 1933, 7 U.S.C. $\$ \S 601-641$ (2006).

${ }^{48}$ Social Security Act of 1935, ch. 531, 49 Stat. 620 (codified in scattered sections of 42 U.S.C.).

${ }^{49}$ Fair Labor Standards Act of 1938, 29 U.S.C. $\$ \S 201-219$ (2006).

50 This statute was declared unconstitutional by the Supreme Court in Schechter Poultry Corp. v. United States, 295 U.S. 495, 541-42 (1935). Its means for excluding blacks remain instructive since the NIRA was the direct predecessor of the National Labor Relations Act.

51 Linder, supra note 1, at 1354.

52 See WOLTERS, supra note 43 , at 88-89, 91.

${ }^{53}$ See infra notes 56-61. 
classifications-that allowed employers to implement lower wages for blacks. ${ }^{54}$ Finally, non-enforcement of the codes allowed employers to pay blacks lower wages than required by the codes. ${ }^{55}$

Southern manufacturers, dependent on a large, cheap supply of black labor, argued for an explicit racial differential that would allow them to pay black workers a lower wage than was paid to whites. ${ }^{56}$ These employers relied on the longstanding tradition of paying blacks less than whites, together with their concern over the disruption of the "whole sociological condition" of agricultural areas that would result if blacks were paid higher wages. ${ }^{57}$ One southern employer testified that "a negro makes a much better workman and a much better citizen, insofar as the South is concerned, when he is not paid the highest wage." ${ }^{\circ 8} \mathrm{He}$ and others urged the adoption of "a materially modified wage scale for unskilled colored labor." 59

Mr. J.F. Ames, of the Selma Manufacturing Company in Selma, Alabama, testified in favor of a racial differential in wage rates. Mr. Ames's company employed negro labor, which he considered to be "subnormal" and "unproductive." 60 Relying on the results of intelligence tests administered during World War I, Mr. Ames reached the following conclusions:

The figures given [on the intelligence of colored men] are taken from men who were four, five and even six generations from their native land, in which there has been no progress for centuries. Contact with the superior white race, in all those generations, has not elevated the colored race beyond the position in relative intelligence established by the tests.

If all the past years have failed to make any real impression in the status of their intelligence, can any legislative act take them and immediately advance their capabilities to be equal to those of the white man with whom they must compete in the race for employment? We think not and because of this inherent irradicable element of incapability, any idea is futile that fails to recognize a difference does exist and will always exist, and that a proper difference in wage rates must be applied to meet the inequality.

54 See id.

55 See id.

56 See Ira De A. Reid, Black Wages for Black Men, 12 OPPORTUNITY: J. NEGRO LIFE 73, 73-74 (1934) (describing the arguments for and against the racial differential); see also WOLTERS, supra note 43 , at 98 .

57 WOLTERS, supra note 43 , at 99.

$58 \mathrm{Id}$.

${ }^{59} \mathrm{Id}$.

${ }^{60}$ National Industrial Recovery Administration, Hearing on Application for Exemption from Code of Fair Competition for the Textile Bag Industry in the United States, 73rd Cong. 7 (1933) (statement of J. F. Ames, Selma Manufacturing Company). 
It is to be regretted that the facts are as they are. It is to be regretted that all men are not created free and equal, as some would have us believe. ${ }^{61}$

The proposed "racial differential" was never adopted. Although no reason was ever given, historian Raymond Wolters speculates that "NRA officials knew that important white interests could be placated by instituting the occupational and geographical classifications .... Thus an avowedly racial differential was unnecessary and would serve only to further antagonize an important segment of the black community."62

Having abandoned the explicit racial differential, race discrimination was accomplished through ostensibly race-neutral means: occupational and geographic classifications in the NRA's industry codes. ${ }^{63}$ The codes contained detrimental occupational classifications that excluded jobs performed by blacks, so that minimum wage scales applied mostly to white workers. ${ }^{64}$ Some codes also contained geographical classifications, so that employers could pay lower wages in the South, where most blacks worked. ${ }^{65}$

Some states were inconsistently classified as both northern and southern for the purpose of paying lower minimum wages in industries employing large numbers of black employees. ${ }^{66}$ As one example, Delaware was classified as being in the North with respect to 449 industry codes but was classified as being in the South with respect to the fertilizer industry. ${ }^{67}$ The reason? Ninety percent of workers in the Delaware fertilizer industry were black. 68 Black leaders concluded, "[T] these variations is the presence or absence of Negro labor. Where most workers in a given territory are Negro, that section is called South and inflicted with low wage rates. Where Negroes are negligible, the procedure is reversed." 69

${ }^{61} \mathrm{Id}$. at 14-15. One wonders about the quality of "intelligence" tests as they existed during World War I (and now). And if African-American workers were "subnormal' and "unproductive," why did Mr. Ames employ so many, seemingly against his and his company's self-interest? I note that Mr. Ames's testimony was accepted without challenge or rebuttal at that hearing.

62 WOLTERS, supra note 43 , at 159 n.22.

63 See id. at 124 ("Although the word 'Negro' was not mentioned in any of the NRA codes, there were several provisions which enabled employers to pay white workers more than blacks."). According to Marc Linder, "[D]iscrimination against blacks permeated the structure and enforcement of the industry codes." Linder, supra note 1, at 1354.

64 Farhang \& Katznelson, supra note 14, at 7, 12; Linder, supra note 1, at 1355.

65 Linder, supra note 1, at 1354-55.

66 Id. at 1355.

${ }^{67} \mathrm{Id}$.

$68 \mathrm{Id}$.

${ }^{69}$ WoltERS, supra note 43, at 129 (quoting John P. Davis, Speech to the 25th 
Lastly, the lack of enforcement of NRA codes, allowing employers to easily evade them by paying blacks less than prescribed wages, prompted great skepticism among blacks. In the South, the local boards responsible for compliance were unsympathetic to black complainants alleging unfair treatment. ${ }^{70}$ Southern blacks were appropriately critical of the federal government's ability to enforce the NRA:

Negro employees in the South ... "[h]ave very grave doubts as to the ability of the Federal Government to compel compliance with the code." They know how deliberately public policy in the South completely disregards the provisions of the Fourteenth and Fifteenth Amendments to the Federal Constitution. They feel that if the government is powerless to enforce the provisions of these measures, it will be equally as powerless to enforce the provisions of the codes. ${ }^{71}$

That skepticism was widely shared. The NRA prompted the following response from Ira De A. Reid, of the National Urban League, who wrote that "the Negro's initial attitude toward the national recovery act is best reflected in the interpretation of initials given by one observer who called it 'Negro Riddance Act." "72

\section{B. Agricultural Adjustment Administration (1933)}

The Agricultural Adjustment Administration (AAA) focused directly on the agricultural sector and sought to raise farmers' incomes by raising prices for crops. However, it succeeded principally in raising only the incomes of already wealthy white farmers. As described by Ira De A. Reid, "So far as the Negroes in the South are concerned the AAA [and other New Deal Agencies] might just as well be administered by the Ku Klux Klan."73

The racism in the AAA lay in the manner of its administration, both at the federal and local levels. Henry Wallace, Roosevelt's Secretary of Agriculture, was primarily responsible for the AAA and its programs. ${ }^{74}$

\footnotetext{
Annual Conference of the NAACP (1934)).

${ }^{70} \mathrm{Id}$. at $133-34$.

${ }^{71}$ Reid, supra note 56, at 76.

72 Lewis Caldwell, Jr., What the NRA is Doing to the Race!, CHI. DEFENDER, May 26, 1934, at 10 (quoting Ira De A. Reid). The subtitles of Caldwell's article describe the African American experience of the New Deal: “'New Deal' Rapidly Becoming 'Raw Deal' for Dark Americans ... Congress Winks at Discrimination." Other interpretations of the NRA in the black press included "Negro Removal Act" and "Negroes Rarely Allowed." Id.; see also WOLTERS, supra note 43, at 134.

73 Caldwell, supra note 72, at 10.

74 Id; DAVID CONRAD, THE FORGOTTEN FARMERS: THE STORY OF SHARECROPPERS IN THE NEW DEAL 37 (1965).
} 
"Henry Wallace ... especially feared antagonizing Southerners on the race issue. No other department was as controlled by white supremacists both in the bureaucracy and in Congress as was the Department of Agriculture."75 $\mathrm{He}$ and other figures in the Administration were apprehensive about supporting black rights, which would disrupt the existing structure of Southern agriculture. ${ }^{76}$ Indeed, in 1935 , administrators who supported black tenant farmers "were forced to resign from the New Deal's agricultural administrations."77 Finally, large Southern agriculturalists had disproportionate influence on the program through the Farm Bureau: "[M]any southern landlords [opposed] any government program that proposed to give tenants, especially black tenants, an independent source of income."78

The program, especially with respect to cotton production, was a disaster for black farmers:

The crop reduction policy had especially severe consequences for the black tenant farmers and sharecroppers who grew cotton in the South. To induce higher prices for cotton in the marketplace, the AAA would limit the acreage dedicated to cotton farming. The agency then would allocate a reduced number of acres to each white planter-landowner. Invariably, the first acres to be eliminated from production by these landowners were those worked by black tenant farmers and sharecroppers. ${ }^{79}$

In this way, large numbers of black farmers and agricultural workers were thrown out of work.

In exchange for voluntarily reducing their cultivated acreage, farmers received government benefit payments to sustain their incomes. ${ }^{80}$ Government money was distributed to white landlords and owners, who in turn were supposed to act as trustees for their black tenants. ${ }^{81}$ The possibilities for abuse in this system are manifest. In practice, white farmers would either keep the payments for themselves or share only a meager amount with their black tenants. ${ }^{82}$ Disputes surrounding these payments and abusive practices were adjudicated before elected local county committees,

75 SITKOFF, supra note 1 , at 44.

76 Id. at $43-44$.

77 WOLTERS, supra note 43 , at 56-57. For an extended discussion of the purge, more sympathetic to Wallace, see CONRAD, supra note 74, at 136-53.

78 WOLTERS, supra note 43 , at 11, 13-15; CONRAD, supra note 74 , at 52-54.

79 Linder, supra note 1 , at 1361 .

80 WOLTERS, supra note 43 , at 21.

81 Id. at 22-24.

82 Linder, supra note 1 , at 1363. 
which were composed of white landlords, associates, and white tenants. ${ }^{83}$ "[T]hroughout the South, not a single black farmer served on a county committee." 84 Ruling rarely for tenants, these all-white committees saw to it that white farm owners received almost all the benefits of this program. ${ }^{85}$

The AAA program, intended to ease the poverty and hardship faced by poor southern farmers, did the opposite for black farmers: it exacerbated their poverty and despair. The chief administrators of the AAA program were well aware of the profoundly negative effects of the program on black farmers. ${ }^{86}$ They and President Roosevelt, however, were unwilling to intervene to improve the welfare of blacks. ${ }^{87}$ Any such course of action might derail southern support for the New Deal and imperil the whole legislative agenda. ${ }^{88}$

\section{The Social Security Act (1935)}

While the NIRA and the AAA relied on racist administration to exclude blacks, the Social Security Act was more explicit. First, most southern blacks were excluded from old-age benefits and unemployment insurance by explicit exclusion of agricultural and domestic labor. ${ }^{89}$ Seemingly neutral on its face, the occupational exclusion of agricultural and domestic employees was well-understood to be a proxy for the exclusion of most black employees. ${ }^{90}$ Second, blacks were further excluded from the unemployment insurance program by the southern demand for local, rather than national, administration of benefits. ${ }^{91}$ In this way, even blacks not excluded through occupational exclusion could be excluded through discriminatory administration of benefits at the state level.

The racism inherent in the exclusion of agricultural and domestic workers becomes more apparent by examining the drafting history of the SSA. As originally proposed, the legislation included all workers:

"We are opposed to exclusions of any specific industries within the

83 WOLTERS, supra note 43 , at 29.

84 Id.; see also STTKOFF, supra note 1, at 53.

85 WOLTERS, supra note 43 , at 30.

${ }^{86} \mathrm{Id}$. at $30-33$.

${ }^{87}$ Linder, supra note 1 , at 1362-63.

88 Id. at 1362.

${ }^{89}$ KATZNELSON, supra note 1, at 22; LIEBERMAN, supra note 31, at 25 ("In order to pass national old-age and unemployment insurance plans, the Roosevelt administration had to compromise inclusiveness and accept the exclusion of agricultural and domestic employees from the program, with notably imbalanced racial consequences.").

90 See infra notes 93-94 and accompanying text.

91 KATZNELSON, supra note 1, at 22-23; LIEBERMAN, supra note 31, at 25-26. 
Federal Act" ... "[A]gricultural workers, domestic servants, home workers, and the many self-employed people constitute large groups in the population who have received little attention. In these groups are many who are at the very bottom of the economic scale." 92

Dr. E.E. Witte, executive director of the Committee on Economic Security, testified regarding the inclusive scope of the original proposal:

It is a fact that, as the bill stands, it attempts to cover the entire employed population. It is a fact that we cannot overlook that no matter whether a person works in a small establishment or a large establishment, whether he works on a farm or whether he works as a domestic servant, or whether he works in a factory, there is one common characteristic, which is that everybody grows old ... [W]e are presenting a program which would cover the entire employed population. ${ }^{93}$

However, despite these inclusive intentions, Congress and the Roosevelt Administration acquiesced in southern racism by agreeing to exclude agricultural and domestic workers:

The Old-Age Insurance provisions of the Social Security Act were founded on racial exclusion. In order to make a national program of old-age benefits palatable to powerful southern congressional barons, the Roosevelt administration acceded to a southern amendment excluding agricultural and domestic employees from OAI coverage. This provision alone eliminated more than half of the African Americans in the labor force and over threefifths of black southern workers. The systematic exclusion of blacks through occupational classifications was crucial to the passage of the act. ${ }^{94}$

The race issue emerged overtly in debate over the provision of old-age benefits and the possibility of distinguishing between classes of people entitled to benefits. It emerged in the following colloquy between Representative Howard W. Smith of Virginia and Representative Thomas Jenkins of Ohio:

Mr. Smith. I might add, though, that of our 116,000 [applicants for benefits] practically 25 percent are of one class that will probably qualify 100 percent.

92 KATZNELSON, supra note 1, at 43 (quoting U.S. Committee on Economic Security, Report to the President, 18, 49 (1935)).

93 Economic Security Act: Hearings on H.R. 4120 Before the H. Comm. on Ways \& Means, 74th Cong. 108 (1935) [hereinafter SSA Hearings] (statement of Dr. E.E. Witte, Executive Director, Committee on Economic Security) (emphasis added).

94 Robert C. Lieberman, Race, Institutions, and the Administration of Social Policy, 19 SOC. SCI. HIST. 511, 514-15 (1995) (citation omitted). 
Mr. Jenkins. I was interested in the statement the gentleman made that practically 25 percent of the people over 65 in his State would be within one class. Would the gentleman state what class he means by that?

Mr. Smith. Of course, in the South we have a great many colored people, and they are largely of the laboring class.

Mr. Jenkins. That is what I thought the gentleman had in mind. I should like to ask the gentleman, and also any member of this committee, whether in this law it is contemplated that there be any loophole by which any state could discriminate against any class of people?

Mr. Smith. No, sir; I do not think so, and you will not find in my remarks any suggestion to that effect. It just so happens that that race is in our State very much of the laboring class and farm laboring class. But you will find no suggestion in my remarks of any suggested amendment that would be unconstitutional, if I may use that expression.

Mr. Jenkins. I am glad that the gentleman did not intend that. I can see that there might be a possibility, if too much leverage is given to the States in their enacting a law to provide funds to match our $\$ 15$ contribution, that they might specify that the old-age pension should be distributed according to groups.

Mr. Vinson. Do you think that that would be seriously considered constitutional?

Mr. Smith. Of course not.

Mr. Vinson. They do not do that in Ohio, do they?

Mr. Jenkins. No, and we do not keep them from voting in Ohio, either.

Mr. Smith. We do not keep them from voting in Virginia. There is an educational qualification, and a great many of them vote who are qualified. $^{95}$

This colloquy demonstrates that representatives on both sides of the issue were acutely aware of the southern desire to exclude blacks from federal benefits. Representative Smith, a well-known obstructionist with respect to black civil rights, shows his awareness of both how many blacks might be

95 SSA Hearings, supra note 93, at 976-77 (emphasis added); see also LIEBERMAN, supra note 31 , at $43-47$. 
entitled to benefits and consciousness of the predominance of blacks among domestic and agricultural employees. ${ }^{96}$ Scholars have reached the conclusion that the exclusion of agricultural and domestic workers in the SSA was intended to exclude blacks from the benefits of the legislation. ${ }^{97}$ In addition to supporting the occupational exclusion, southern congressmen also objected to the federal administration of benefits as an intrusion on state sovereignty which threatened to destabilize white supremacy in the South. ${ }^{98}$

Congress's racism and indifference to the welfare of blacks is apparent in its willingness to ignore testimony regarding the unfairness of the legislation toward the black community. For example, George E. Haynes, representing the Federal Council of Churches of Christ, pleaded with the House committee to add a provision forbidding race discrimination in the distribution of benefits, to limit the racist abuses made possible by local administration:

I wish to urge ... that there be included in this bill a clause or clauses to provide that there shall be no discrimination on account of race or color in administration of services or benefits to any person otherwise eligible.

In support of our urgent request I wish to submit evidence to show that in the past the distribution and administration of Federal funds, both under the regular services furnished by the States, with the help of Federal funds, as well as in the emergency measures that have been carried out under legislation for recovery, there have been repeated, widespread, and continued discrimination on account of race or color as a result of which Negro men, women, and children did not share equitably and fairly in the distribution of the benefits accruing from the expenditure of such Federal Funds. 99

Charles Hamilton Houston, on behalf of the NAACP, testified that because the old-age annuity was available only to persons in formal employment relationships, a large number of black tenant farmers,

96 When statutory reform occurred in 1954, Smith opposed the extension of old-age pension benefits to blacks. See LIEBERMAN, supra note 31 , at 113-16. Smith also prominently obstructed passage of civil rights legislation in 1964. See id.

97 See Jill Quadagno, THE COlor of Welfare: How RaCisM Undermines THE War on Poverty 19-20 (1994); Jill Quadagno, The Transformation OF Old Age SeCURITY: Class aND Politics IN THE AMERICAN Welfare STATE 115-16 (1988); Lieberman, supra note 94, at 512, 515; Robert C. Lieberman, Race and the Organization of Welfare Policy, in CLASSIFYING BY RACE 159-61 (Paul E. Peterson ed., 1995).

98 LIEBERMAN, supra note 31 , at 28,36 (" $[\mathrm{R}]$ egardless of their general political outlook, Southerners tended to coalesce in opposition to racial liberalism and encroaching federal power.").

99 SSA Hearings, supra note 93, at 598 (statement of George Haynes, Federal Council of Churches of Christ in America). 
sharecroppers, domestic servants and the unemployed would not benefit. ${ }^{100}$ Regarding unemployment insurance, Houston testified such insurance would not help blacks unless agricultural and domestic employees were explicitly included:

[I] call the committee's attention to the fact that the definition of those who are to benefit under the unemployment-insurance provision is left up to the respective States. Now, where the Negro population is in the majority, or in largest numbers, you have the Negroes in occupations which, either under workmen's compensation acts or any other sort of legislation or other economic-insurance protection, are excluded from the benefits of the act.

In these States, where your Negro population is heaviest, you will find the majority of Negroes engaged either in farming or else in domestic service, so that, unless we have some provisions which will expressly extend the provisions of the bill to include domestic servants and agricultural workers, I submit that the bill is inadequate on the unemployment-compensation provision. ${ }^{101}$

Houston also testified before the Senate regarding the exclusion of agricultural and domestic labor:

If we follow the history of the workmen's compensation acts, we know that two great classes of workers who will be excluded from the benefit of unemployment insurance; they are agricultural workers and domestic workers. Again, 3 out of every 5 Negro workers drop through the holes of the sieve. 102

Indifferent to the negative effects on blacks, and appeasing Southern Democrats, Congress passed the SSA with a statutory exclusion of agricultural and domestic employees from both old-age and unemployment benefits. ${ }^{103}$

${ }^{100} \mathrm{Id}$. at 796-97 (statement of Charles Hamilton Houston, NAACP).

${ }^{101} \mathrm{Id}$. at 797-98 (statement of Charles Hamilton Houston, NAACP).

102 Id. at 646 (statement of Charles Hamilton Houston, NAACP).

103 With respect to old-age benefits, $\S 210$ (b) of the SSA provided that the following services are excluded even though performed within the United States: (1) agricultural labor; and (2) domestic service in a private home. See Social Security Act, ch. 531, tit. II, $\S 210(\mathrm{~b})(1)-(2), 49$ Stat. 620,625 (1935). With respect to unemployment compensation, $\S 907$ (c) provided, "The term 'employment' means any service ... performed within the United States by an employee for his employer, except - (1) Agricultural labor; (2) Domestic service in a private home." Social Security Act, ch. 531, tit. IX, § 907(c)(1)(2), 49 Stat. 620, 643 (1935). 


\section{The Fair Labor Standards Act (1938)}

Like the Social Security Act, the racism in the Fair Labor Standards Act (FLSA) becomes apparent through the purposeful exclusion of most black employees by proxy from an originally inclusive proposal. President Roosevelt's initial desire in the FLSA was to protect all workers, agricultural and industrial, by establishing minimum wages and maximum working hours. 104 The earliest versions of this legislation, however, excluded agricultural workers explicitly, and domestic workers implicitly, continuing the pattern set in preceding statutes. ${ }^{105}$ As stated by one witness during hearings on the FLSA:

No purpose will be served by beating around the bush. You, Mr. Chairman, and all your associates on this Committee know as well as I do that agricultural laborers have been explicitly excluded from participation in any of the benefits of New Deal legislation, from the late (but not greatly lamented) N.R.A., down through the A.A.A., the Wagner-Connery Labor Relations Act [NLRA] and the Social Security Act, for the simple and effective reason that it has been deemed politically certain that their inclusion would have spelled death of the legislation in Congress. And now, in this proposed Black-Connery wages and hours bill, agricultural laborers are again explicitly excluded. ${ }^{106}$

Unlike the preceding Social Security Act, however, southern members of Congress who debated the FLSA were more open about their racist desires to exclude blacks from FLSA protections. The hearings and debate on the FLSA reveal direct evidence of intentional discrimination against blacks because of their race. For example, Senator 'Cotton' Ed Smith from South Carolina complained bitterly about the deterioration in American civilization he perceived from the introduction of blacks into political society as a result of the Reconstruction Amendments. ${ }^{107}$ Senator Smith continued:

Every Senator present knows that the antilynching bill is introduced for no other reason in the world than a desire to get the votes of a certain race in

104 KATZNELSON, supra note 1 , at 58.

105 Id. Domestic workers were excluded implicitly because the FLSA only protected workers "engaged in commerce or in the production of goods for commerce." Id. (internal citation and quotation omitted).

106 JAMES R. WASON, LEGISLATIVE HISTORY OF THE EXCLUSION OF AGRICULTURAL EMPLOYEES FROM THE NATIONAL LABOR RELATIONS ACT, 1935, AND THE FAIR LABOR STANDARDS ACT OF 1938, at 11 (1966) (statement of Gardner Jackson, Chairman, National Committee on Rural and Social Planning); KATZNELSON, supra note 1, at 5859.

10781 Cong. Rec. 7881-82 (1937). 
this country.

Antilynching, two-thirds rule, and, last of all, this unconscionable-I shall not attempt to use the proper adjective to designate, in my opinion, this bill [the FLSA]! Any man on this floor who has sense enough to read the English language knows that the main object of this bill is, by human legislation, to overcome the splendid gifts of God to the South. ${ }^{108}$

Apparently, in Smith's view, God's "gifts to the South" included a fully exploitable black population to provide cheap labor. ${ }^{109}$

Representative J. Mark Wilcox of Florida was explicit in expressing the concerns of southern whites about the FLSA:

Then there is another matter of great importance in the South, and that is the problem of our Negro labor. There has always been a difference in the wage scale of white and colored labor. So long as Florida people are permitted to handle the matter, this delicate and perplexing problem can be adjusted; but the Federal Government knows no color line and of necessity it cannot make any distinction between the races. We may rest assured, therefore, that ... it will prescribe the same wage for the Negro that it prescribes for the white man.... [T]hose of us who know the true situation know that it just will not work in the South. You cannot put the Negro and the white man on the same basis and get away with it. Not only would such a situation result in grave social and racial conflicts but it would also result in throwing the Negro out of employment and in making him a public charge. There just is not any sense in intensifying this racial problem in the South, and this bill cannot help but produce such a result.

... This bill, like the antilynching bill, is another political gold brick for the Negro, but this time the white laborer is also included in the scheme. ${ }^{110}$

Echoing concerns that kept wages lower for blacks than for whites during the NRA, Wilcox feared that equal wages would disrupt the racist, segregated social structure of the South and that federal standards would provoke serious racial conflicts in the South. ${ }^{111}$ Similarly, Martin Dies of Texas expressed concern about the "racial question" inherent in the FLSA because "what is prescribed for one race must be prescribed for the others, and you cannot

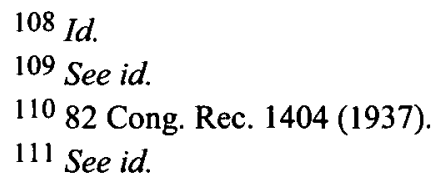


prescribe the same wages for the black man as for the white man."112 Congressman Cox of Georgia was also concerned about federal interference in southern society:

The organized Negro groups of the country are supporting [the FLSA] because it will, in destroying State sovereignty and local self-determination, render easier the elimination and disappearance of racial and social distinctions, and by the concentration of this vast and despotic power in a political board or administrator in Washington throw into the political field the determination of the standards and customs which shall determine the relationship of our various groups of people in the South. ${ }^{113}$

Federal enforcement of equal wages for blacks and whites in the South would have undermined powerfully some of the key premises supporting southern racism. Equal pay would have sent a powerful message of the equal worth and dignity of black workers. Equal pay would have made it easier for black workers to free themselves from economic dependence on southern whites intent on oppressing them. Federal enforcement of fair labor standards would have given blacks a powerful federal ally in their fight for equality. Southern congressmen could not countenance such radical changes in the ability of southern whites to exploit southern blacks.

As in its deliberations on the Social Security Act, Congress's willingness to embrace racism and to ignore the welfare of blacks is apparent in its indifference to the testimony of black leaders about the effects of the FLSA on black workers. John P. Davis, representing the National Negro Congress, testified about the racially discriminatory provisions of prior legislation, such as the NRA and the Social Security Act:

In the period of the N.R.A. code hearings Negro workers were helpless to defend themselves against demands made, especially by representatives of southern industry, for longer hours and lower wages for those occupations, industries and geographical divisions of industries in which the predominant labor supply was Negro. Unorganized and without perceptible collectivebargaining power, the Negro worker was soon singled out by pressure groups of employers as the legitimate victim for all manner of various differentials. ${ }^{114}$

112 KATZNELSON, supra note 1 , at 60.

11382 Cong. Rec. App. 442 (1937) (emphasis added).

114 The Fair Labor Standards Act of 1937: Joint Hearings on S. 2475 and H.R. 
Describing the effects of possible occupational differentials detrimental to blacks in minimum wages, Davis testified that "[t]here is not a single thing in this part of the bill that will prevent the same type of ruthless exploitation of Negro workers which was their lot under the N.R.A." 15 Davis pointedly described how the exclusion of agricultural and domestic workers made the New Deal an empty promise for blacks:

This bill is supposed to be intended to help those workers whose lack of collective bargaining power renders them capable of exploitation by employers. As it stands, it does no such thing.

The economic crisis has not lifted for the Negro people. Because they are largely unskilled workers, reemployment for them has been slight. Negro domestic and agricultural laborers-representing the bulk of Negro labor-have had no benefits from the Social Security Act or other protective legislation. ${ }^{116}$

Aware of, yet remaining indifferent to the exclusion of blacks, once again Congress acquiesced in southern racism by excluding most blacks from the FLSA. Once again, the device was exclusion by proxy by excluding agricultural employees. Although the agricultural worker exclusion from minimum wage protection has been repealed, farm workers employed on large farms remain excluded from the FLSA's overtime and maximum hours protections. $^{117}$

7200 Before the S. Comm. on Education \& Labor and the H. Comm. on Labor, 75th Cong. 571 (1937) [hereinafter FLSA Hearings] (statement of John P. Davis, National Negro Congress).

${ }^{115} \mathrm{Id}$. at 573. Davis described some of the rationalizations employed under the NRA for producing lower wages for blacks than for whites:

[T] he Labor Standards Board created by the bill [can] fix minimum wages by occupations and not by industries... The Board is further directed to base its wage minima upon such factors as cost of living and the value of the service or class of service rendered. Here the floodgates are open for confusing standards of living with costs of living, for introducing such figments of employer imagination as those common in N.R.A. days which said, first, that it cost Negroes less to live, and, second, that Negro workers were less efficient.

Id. added)

116 Id. at 573-74 (statement of John P. Davis, National Negro Congress) (emphasis

117 Linder, supra note 1, at 1335. 


\section{THE NATIONAL LABOR RELATIONS ACT AND ITS EXCLUSION OF AGRICULTURAL AND DOMESTIC EMPLOYEES}

Although New Deal Era statutes like the NIRA, the SSA, and the FLSA provided some economic relief and protection for some blacks, these major statutes were insignificant, or worse, for most blacks. As Charles Hamilton Houston, commenting on the Social Security Act, aptly described, " $[\mathrm{F}] \mathrm{rom}$ the Negro's point of view,' the [legislation] 'looks like a sieve with the holes just big enough for the majority of Negroes to fall through."'118 As we have seen, the "holes in the sieve" were crafted knowingly to exclude most blacks from the economic and legal protections provided to white, industrial employees. One of the major devices used to exclude most blacks by proxy was the exclusion of agricultural and domestic workers. There is little reason to think that the same exclusion of agricultural and domestic workers from the National Labor Relations Act was different in meaning than the similar exclusions in other New Deal legislation.

\section{A. The Legislative History of Section 152(3)}

There was no discussion of race and little discussion of agricultural workers in debates on the NLRA. Unlike the legislative record of the FLSA and other New Deal statutes, there is no direct evidence in the debates demonstrating overtly the racist southern interests in excluding most black employees from the legislation. There is, however, evidence that the politics shaping the NLRA were the same as the politics that shaped the Social Security and Fair Labor Standards Acts.

As in the SSA and the FLSA, congressional intent to exclude blacks by proxy can be inferred from the alteration of a proposal that began as fully inclusive. The original draft of the legislation that became the National Labor Relations Act, like the first version of Social Security legislation, contained no exclusion of agricultural and domestic workers. ${ }^{119}$ The original legislation intended to protect the rights of all employees to organize and bargain collectively. ${ }^{120}$ The bill introduced by Senator Wagner defined "employee" as "any person employed by an employer under any contract of hire, oral or written, express or implied, including all contracts entered into by helpers and assistants of employees, whether paid by employer or employee, if

118 See Wolters, supra note 17, at 194.

119 National Labor Relations Act: Hearings on S. 2926 Before the S. Comm. on Education \& Labor, 73d Cong. 695 (1935), reprinted in 1 LEGISLATIVE HISTORY OF THE NATIONAL LABOR RELATIONS ACT 1935, at 2 (1949) [hereinafter NLRA Hearings]; see infra notes 121-22 and accompanying text.

${ }^{120}$ NLRA Hearings, supra note 119 , at 2; see infra notes $121-22$ and accompanying text. 
employed with the knowledge, actual or constructive, of the employer."121 During hearings on the original bill, Senator David Walsh explained that the bill, as drafted, did not make any exemption for employers of small or large groups of employees:

As drafted, it (the bill) would apply to a farmer or a housewife, possibly, who employed two persons.... [I]t would permit an organization of employees who work on a farm; and would require the farmer to actually recognize their representatives, and deal with them in the matter of collective bargaining. ${ }^{122}$

There was little discussion during the hearings about either race or agricultural employees. ${ }^{123}$ Some objections to the inclusion of agricultural employees were raised by representatives of farm owners. A. F. Thompson objected that the legislation applied "to every farmer in the State of Wisconsin who has a hired man or any domestic help." $124 \mathrm{He}$ anticipated the "difficulty which farmers will have in understanding the purpose of this act."125 Fred Brenckman, Washington Representative of the National Grange, argued:

[I]t would manifestly be absurd to place hired farm labor in the same category with the industrial labor, and to give the proposed national labor board jurisdiction over the farmer's hired help.

If farm labor is poorly paid in the United States today, then it can be said with emphasis that the farmer and his family are still more poorly paid. ${ }^{126}$

Some scholars have posited that administrative concerns such as these, and not the desire to exclude blacks, motivated the exclusion of agricultural workers and domestics. ${ }^{127}$

121 Kenneth M. Casebeer, Drafting Wagner's Act: Leon Keyserling and the Precommittee Drafts of the Labor Disputes Act and the National Labor Relations Act, 11 INDUS. REL. L. J. 73, 114 (1989).

122 WASON, supra note 106, at 3; see also KATZNELSON, supra note 1, at 57.

123 FRYMER, supra note 1, at 28 ("Even on this seemingly certain indicator of southern influence, the notable absence of agricultural and domestic workers from the NLRA, the legislative history reflects very little discussion of the reasons for their exclusion."); KATZNELSON, supra note 1, at 57.

124 NLRA Hearings, supra note 119, at 1005 (statement of A. F. Thompson).

125 Id.

${ }^{126}$ Id. at 1038 (brief of Fred Brenckman, The National Grange).

127 Cf. Gareth Davies \& Martha Derthick, Race and Social Welfare Policy: The Social Security Act of 1935, 112 POL. SCI. Q. 217 (1997) (arguing that the exclusion of 
The bill was then referred back to the Senate Committee on Education and Labor which, in executive session, amended the bill to exclude agricultural and domestic workers for the first time: "The term 'employee' shall include any employee ... but shall not include any individual employed as an agricultural laborer, or in the domestic service of any family or person at his home ...."128 The amended bill also excluded from the definition of "employer" persons employing fewer than ten employees. ${ }^{129}$ The accompanying report suggested that these amendments responded to "propaganda" and "misstatements" regarding the objectives of the bill. 130 The report clarified that "[a]s now drafted, the bill does not relate to employment as a domestic servant or as an agricultural laborer. It does not affect establishments in which less than 10 persons are employed."131 Apparently, southern members of the committee, Senators Hugo Black of Alabama and Park Trammell of Florida, worked with three Democrats from rural states to craft the exclusion. ${ }^{132}$ Once the exclusion appeared in the bill, it remained unchanged in all subsequent versions of the bill in both houses of Congress. ${ }^{133}$ As ultimately passed by the Senate, the NLRA excluded agricultural and domestic workers but contained no exemption for small employers. ${ }^{134}$

The versions of the legislation debated on the House side excluded agricultural and domestic employees. Representative Marcantonio, the principal voice of dissent regarding the exclusion of agricultural workers, argued repeatedly for their inclusion:

I also find myself unable to agree with the committee in its exclusion of

agricultural and domestic workers from the Social Security Act was motivated by administrative difficulties, not race).

128 See National Labor Relations Act, 49 Stat. 449, 450 (1935) (emphasis added).

129 S. Rep. No. 79-1184, at 1 (1934), reprinted in 1 LEGISLATIVE HISTORY OF THE NATIONAL LABOR RELATIONS ACT 1935, at 1099 (1949).

${ }^{130}$ Id.

131 Id.

132 KATZNELSON, supra note 1 , at 57,195 n.16-17.

133 WASON, supra note 106, at 4.

134 A Senate Report explained the failure to exclude small employers:

For administrative reasons, the committee deemed it wise not to include under the bill agricultural laborers, persons in domestic service of any family or person in his home, or any individual employed by his parent or spouse. But after deliberation, the committee decided not to exclude employees working for very small employer units. The rights of employees should not be denied because of the size of the plant in which they work.

S. Rep. No. 74-573, at 7 (1935), reprinted in 2 LEgISLATIVE HISTORY OF THE NATIONAL LABOR RELATIONS ACT 1935, at 2306 (1949). 
agricultural workers. It is a matter of plain fact that the worst conditions in the United States are the conditions among the agricultural workers. They have been brought to the public attention many times; for example, by the investigations of the National Child Labor Committee into the horrible conditions, especially as affecting children, in the beet-sugar fields. The complete denial of civil liberty and the reign of terror in the Imperial Valley have been the subject of investigation by Government agents. ${ }^{135}$

After describing the violence used to terrorize supporters of a farm worker union in Arkansas, Marcantonio described the plight of farm workers:

What these people in Arkansas are organizing against is the most outrageous exploitation in America. The plantation system of itself is damnable. It combines the worst evils of feudalism and capitalism. The overseers on plantations go armed.

A continuance of these conditions is preparing the way for a desperate revolt of virtual serfs. Unless the right to organize peacefully can be guaranteed we shall have a continuance of virtual slavery until the day of revolt. ${ }^{136}$

Despite the minimal discussion of agricultural workers, and the lack of discussion of race, there is evidence of racism underlying the exclusion in the politics that shaped the NLRA. The Congress that enacted the NLRA was the same Congress that heard evidence of racism and yet enacted the exclusion of agricultural and domestic workers in the Social Security Act. Both statutes were enacted within a single month. Furthermore, the politics of the New Deal Congresses, all of which accommodated southern racism, were the same.

Evidence of these politics comes from Leon Keyserling, the principal drafter of the NLRA in its original form. ${ }^{137}$ When asked why the decision was made to exclude agricultural workers from the legislation, Keyserling responded:

The Senator [Wagner] originally left out agricultural workers for purely

135 H.R. Rep. No. 74-969, at 27 (1935), in 2 LEgISLATIVE History OF THE NATIONAL LABOR RELATIONS ACT 1935, at 2936-37 (1949) (statement of Rep. Marcantonio).

136 H.R. Rep. No. 74-969, at 28 (1935), reprinted in 2 LEGISLATIVE HisTORY OF THE NATIONAL LABOR RELATIONS ACT, 1935, at 2937 (1949) (statement of Rep. Marcantonio).

${ }^{137}$ Keyserling was Senator Wagner's only legislative aide between 1933 to 1938 and was primarily responsible for drafting the original bill. Kenneth M. Casebeer, Holder of the Pen: An Interview with Leon Keyserling on Drafting the Wagner Act, 42 U. MIAMI L. REV. 285, 296-300 (1987). 
political reasons. The difficulty of getting the bill through the Senate with such a disproportionate representation of rural people, allied to management and not to agricultural labor, would have increased beyond all reason the odds against getting the Act passed. 138

Keyserling commented that Senator Wagner wanted protection for agricultural workers, "but he just saw in the Senate and its almost dominant rural composition at the time, a farm interest composition-the chairmen of most of the committees were controlled by southerners-that putting in farm labor would be too much to carry ...."139 Senator Wagner wanted passage of the legislation more than he wanted to fight and risk the legislation to protect predominantly black farm workers. The reason for excluding agricultural and domestic workers, this time as before, was to appease the racist instincts of powerful southern legislators whose support and votes were needed to pass the legislation.

Congress's failure to prohibit unions from discriminating against black employees provides further evidence of its acquiescence in the racial discrimination that underlies the NLRA. ${ }^{140}$ In their briefs filed before Congress, black leaders advocated for an antidiscrimination provision and made Congress fully aware of wanton union discrimination against blacks. William E. Taylor, Chairman of the NAACP's Legislative Committee, described the union hostility facing black employees:

Organized labor is hostile to colored people. Practically every labor organization in the country denies Negroes the right of membership therein. Those which admit colored people restrict their employment to the least desirable work, and, because of the race or color of the darker members of the union, deny them the right to the skilled and, in some instances, the

${ }^{138} \mathrm{Id}$. at 334 . Keyserling also described interaction between Senator Wagner and Agriculture Secretary Wallace:

[Senator Wagner] said that if [Agriculture Secretary] Henry Wallace would write him a letter asking that agricultural workers be included, he would include them and make the fight for it. But if Wallace wasn't willing to fight for it, [Wagner] couldn't undertake it alone.... Wallace was very careful. He was not prepared to fight for the Wagner Act for agricultural labor.

Id. Wallace never produced such a written request, and so agricultural workers were excluded from the legislation without a fight. Commenting on Wallace's motives, Keyserling described Wallace as "entirely beholden to the chairmen of the agricultural committees in the Senate and the House, who were all big Southern landowners like Senator Smith and Congressman Bankhead, who later became Speaker of the House and was the father of Tallulah Bankhead." Id. at 334 \& n.97-98.

139 Id. at 359.

140 See FRYMER, supra note 1, at 29; GolUBOFF, supra note 1, at 37,180 ; KATZNELSON, supra note 1, at 65. 
semiskilled positions, regardless of their training, skill, or experience. When a factory or job is unionized, the members of the union refuse to work with the colored workers because they do not belong to the union, and refuse to admit the Negroes to the union because of their color. ${ }^{141}$

T. Arnold Hill, representative of the National Urban League, described similar discrimination against blacks. ${ }^{142}$ Both Taylor and Hill recommended specific amendments to the Act prohibiting unions from discriminating against anyone because of race. ${ }^{143} \mathrm{Mr}$. Taylor, for example, recommended amending the legislation to read:

"And provided further, That no labor organization which denies the right of membership therein to or discriminates against any person on account of race, color, or creed, or which refuses to admit members thereto for any reasons not applicable alike to all persons without regard to race, color, or creed, shall be entitled to the benefits of the provisions of this act."144

Senator Wagner supported the NAACP's efforts to add an antidiscrimination provision to the NLRA. ${ }^{145}$

However, any such nondiscrimination provision was strenuously, and successfully, opposed by the American Federation of Labor (AFL), the principal white-dominated federation of craft unions. According to Leon Keyserling, "[t]he Act as originally drafted by Senator Wagner provided that the closed shop should be legal only when there were no restrictions upon members in the labor union to which the majority of workers belonged." 146 In other words, unions that discriminated because of race would not be able to run a closed shop, therefore curtailing severely the union's power. The AFL, however, worked hard to defeat the inclusion of any such provision. As related by Keyserling, "The American Federation of Labor fought bitterly to eliminate this clause and much against his will Senator Wagner had to consent to elimination in order to prevent scuttling of the entire bill." 147 The proposed antidiscrimination amendment was defeated by the AFL, "because they want[ed] to eliminate Negro competitive labor."148 In addition, it is

141 NLRA Hearings, supra note 119, at 1035 (brief of William E. Taylor, Chairman, Legislative Committee, District Branch, NAACP).

${ }^{142} I d$. at $1058-59$ (brief of T. Amold Hill, National Urban League).

143 WOLTERS, supra note 43 , at 183-85.

144 NLRA Hearings, supra note 119, at 1036 (brief of William E. Taylor, Chairman, Legislative Committee, District Branch, NAACP).

145 WOLTERS, supra note 43, at 192 n.26.

146 Id. at 185 .

147 Id.

$148 \mathrm{Id}$. at 187. 
likely that any such non-discrimination provision would have resulted in the loss of southern Democratic support for the bill, and hence loss of the whole bill. 149

Ultimately, the NLRA was enacted with an exclusion for agricultural and domestic workers: "The term 'employee' shall include any employee, . . but shall not include any individual employed as an agricultural laborer, or in the domestic service of any family or person at his home . . ."150 And so it remains today, completely unaltered for 75 years.

\section{B. Interpreting Section 152(3) of the NLRA as Racially Discriminatory}

The only reason for ambiguity regarding the meaning of the NLRA's exclusion of agricultural and domestic workers is that, for the most part, Congress was silent regarding both race and agricultural and domestic workers during debates on the NLRA. Accordingly, the meaning of the exclusion must be inferred from the provision's surrounding context and its effects. That context is rich with evidence of what the exclusion meant and why it was deemed necessary.

The basic politics of the New Deal were constant during the period of enactment of all of the statutes considered here. The price of southern democratic support for New Deal reforms was the exclusion of blacks from federal benefits and protections. Only in this way could Southern Democrats both support the reforms, which benefitted white industrial employees principally, without threatening the political economy of the racist South. Ira Katznelson describes aptly the political calculus regarding the rights to unionize protected in the NLRA:

When [New Deal statutes] passed, unions were only a scant presence in the region, hence not much of a threat. ... The South was willing to support [New Deal legislation] provided these statutes did not threaten Jim Crow. So southern members traded their votes for the exclusion of farmworkers and maids, the most widespread black categories of employment, from the protections offered by these statutes. In circumstances where congressional Republicans were adamantly opposed to these laws, the Democratic Party made these racially relevant adjustments to secure a winning coalition that included southern members of the party. As a result, these new arrangements were friendly to labor but unfriendly to the majority of African Americans who lived below the Mason-Dixon line. Without this fine-tuning, a majority of southern blacks might have had access to protections negotiated by unions that would have quite shaken the political

149 STrKOFF, supra note 1 , at 52.

150 National Labor Relations Act, ch. 372, § 2(3), 49 Stat. 449, 450 (1935) (codified as amended at 29 U.S.C. $\$ 152(3)$ (2006)) (emphasis added). 
economy of segregation. ${ }^{151}$

The appeasement of Southern segregation and racism, consistent throughout the New Deal Era, lay behind the exclusion of agricultural and domestic employees in the National Labor Relations Act.

All of the principal actors responsible for the legislation knew and understood these politics. President Roosevelt, principal architect of all New Deal reforms, compromised his inclusive vision and sacrificed egalitarian and civil rights interests for the sake of enacting legislation remedial for the depressed economy. ${ }^{152}$ Senator Wagner, principal author and advocate in the Senate for the NLRA, knew, understood, and responded to these politics by not fighting for the inclusion of agricultural and domestic workers and not including an anti-discrimination provision in the legislation. ${ }^{153}$ Black leaders such as Charles Hamilton Houston, John P. Davis, William Taylor and T. Arnold Hill knew and understood the effects of the exclusion, and gave evidence to Congress of the poverty and racism faced by black employees that would go unremedied by Congress's exclusion of blacks from the New Deal. ${ }^{154}$ Members of Congress, most intimate with the politics of their institution and having before them the testimony of these black leaders, can not have been ignorant of the racial effects and injuries they caused by excluding agricultural and domestic workers from the NLRA.

Congress acquiesced in, and in effect endorsed, southern racism by making a Faustian pact to exclude black employees by proxy to enable the passage of New Deal legislation. The racism of the South underlying this consistently deployed political compromise found its way into every New Deal enactment. In the NIRA and the AAA, the tools were occupational exclusion and the concession to racist local administration of federal benefits. ${ }^{155}$ In the SSA and the FLSA, the tools were statutory occupational exclusions of agricultural and domestic employees from federal benefits, minimum wages, and overtime protections. ${ }^{156}$ Using the ostensibly raceneutral language of occupational exclusion, Congress enacted raciallytargeted results: the continued economic deprivation of blacks and the preservation of their place at the bottom of the South's economic hierarchy.

The guiding hand of southern racism is palpable even in the silence surrounding the NLRA. Despite the expressed desire to improve the welfare of those most in need, Congress excluded those most in need--black

151 KATZNELSON, supra note 1 , at 55-56.

152 See supra notes $40-45$ and accompanying text.

153 See supra notes 138-39, 145-49 and accompanying text.

154 See supra notes $101-03,114-16,118,141-45$ and accompanying text.

155 See supra notes 63-64, 79-85 and accompanying text.

156 See supra notes 89-90, 106 and accompanying text. 
agricultural and domestic workers-from the possibilities of federally regulated collective bargaining. Although some witnesses expressed concern with the effect of collective bargaining on small family farms, this was not the main reason why Congress excluded all agricultural and domestic employees from the NLRA. ${ }^{157}$ If Congress's main interest had been the protection of small family farmers, Congress could simply have exempted small family farms. Instead, Congress excluded the whole class of agricultural and domestic employees, an exclusion of greatest benefit to the largest, plantation-style agriculturalists in the South whose quasi-slavery, peonage-based method of operation remained untouched. In addition, Congress explicitly rejected size limitations and made the NLRA applicable to all employers of any size. It is also telling that, despite knowledge of the union racism faced by black employees, Congress refused to enact an antidiscrimination provision that would ameliorate that racism. By failing to act to ameliorate racism, Congress acquiesced in rampant union racism against blacks.

In the context of the times, the NLRA's exclusion of agricultural and domestic workers is best understood as a race-neutral device that, by excluding most southern black employees from federal protection, appeased the interests of southern congressmen in preserving an unperturbed plantation-style agricultural economy with minimal federal interference in their segregated society. It simply does not make sense to interpret the exclusion of agricultural and domestic employees-consistent in politics, content, and effect throughout the New Deal Era-as exceptional and not motivated by southern racism in the case of the National Labor Relations Act. It is more reasonable to conclude that, like the other New Deal statutes studied here, the NLRA's exclusion resulted from congressional acquiescence in the racism of southern congressmen, a Faustian pact necessary to enable the passage of any New Deal legislation at all.

\section{THE AgRICULTURAL AND DOMESTIC WORKER EXCLUSION TODAY}

Most of the exclusions of agricultural and domestic workers have been repealed, creating greater racial fairness in the Social Security System and the Fair Labor Standards Act. ${ }^{158}$ Remarkably, despite its racist origins, the

157 See supra Section III.A.

158 See, e.g., Linder, supra note 1, at 1388-92 (showing tabular data and descriptions of repealed exclusions from FLSA coverage). Another provision still excludes agricultural and domestic workers from the maximum hours provision of the FLSA. See 29 U.S.C. $\S \S 207(b), 213$ (a)-(b) (2006). This exclusion denies to these workers, unlike most others, protection against being forced to work unreasonable hours without overtime pay. According to Marc Linder, "[f]arm workers employed on large farms remain today, as they were in 1938 , the only numerically significant group of adult 
National Labor Relations Act still excludes agricultural and domestic workers from the definition of "employee." 159 Because of the exclusion, farm workers and domestics have no federally protected right to organize and bargain collectively. In the absence of protective state legislation, farm workers can be fired for seeking to unionize or acting for their mutual aid and protection. The exclusion thus exacerbates the exploitation and vulnerability of farm and domestic workers at the bottom rungs of the economy.

Today the color of those most affected has changed, but the basic operation and effects of the agricultural exclusion have not. The original southern desire to preserve an exploited, economically deprived non-white agricultural labor force pinned to the bottom of the social and economic hierarchy continues to manifest itself full-force. Although estimates of the size of the farmworker population vary, there are approximately two to three million agricultural workers. ${ }^{160}$ The huge majority, approximately eightythree percent, are Latino. ${ }^{161}$ They live in terrible poverty; the median annual income for migrant farm workers is about $\$ 7,500 .{ }^{162}$ Thirty percent of all farm workers live below the national poverty level, despite being employed. ${ }^{163}$ Statutory exclusions originally intended to keep blacks impoverished and subservient now keep Latino farm and domestic workers subservient.

Because of its racist origins and injurious effects, Section 152(3), like the other exclusions of agricultural and domestic workers, should be eliminated. In this part of the Article, I discuss the two primary strategies for eliminating Section 152(3)-a litigation strategy and a legislative strategy.

\section{A. Litigation Strategy}

The agricultural and domestic worker exclusion is federal action

minimum-wage workers wholly excluded from the maximum hours provision of the FLSA on the basis of a criterion unrelated to the size of the employer." Linder, supra note 1 , at 1389.

159 See 29 U.S.C. $§ 152(3)$, which provides, “The term 'employee' shall include any employee, ... but shall not include any individual employed as an agricultural laborer, or in the domestic service of any family or person at his home ...." (emphasis added).

160 HuMAN COST OF FOOD, supra note 3, at 3.

${ }^{161}$ U.S. Dept. of Labor, Findings from the National Agricultural Workers Survey (NAWS) 2001-2002, at 4 (2005) [hereinafter Survey]. The particular composition of Latino farmworkers is as follows: "72 percent identify as Mexican, seven percent as Mexican-American, one percent as Chicano, and three percent as other Hispanic." Id. at 4. Over half of the farmworkers, $53 \%$, are unauthorized to work in the United States. $I d$. at 3 .

162 Bowe, supra note 6, at 8; SCHLOSSER, surpa note 6, at 79.

163 Survey, supra note 161 , at 47. 
intended to injure a discrete group of people because of their race. It is hard to imagine legislation that should violate equal protection more than this. Yet because an equal protection violation requires proof of discriminatory intent, judicial invalidation of the exclusion is not straightforward.

The most likely constitutional argument for invalidation arises under the Equal Protection Clause. Under the standards articulated in Washington $v$. Davis 164 and Village of Arlington Heights v. Metropolitan Housing Development Corp., ${ }^{165}$ an ostensibly race-neutral government classification will violate the equal protection clause only if it was enacted with discriminatory intent: "[O]fficial action will not be held unconstitutional solely because it results in a racially disproportionate impact.... Proof of racially discriminatory intent or purpose is required to show a violation of the Equal Protection Clause."166 When there is evidence of mixed legislative motives, racial discrimination must be shown to have been a "substantial" or "motivating" factor in the decision to adopt a regulation or statute. ${ }^{167}$ The Court has approved the use of historical evidence to prove discriminatory intent. 168

164426 U.S. 229, 239 (1976). Although the Equal Protection Clause, by its terms, applies only to states, the Court has implied an equal protection guarantee that applies to the federal government under the Due Process Clause of the Fifth Amendment. See Bolling v. Sharpe, 347 U.S. 497, 499 (1954). This equal protection guarantee has the same contours as the Equal Protection Clause. See id. at 500; see also, e.g., Adarand Constructors, Inc. v. Pena, 515 U.S. 200, 224 (1995).

165429 U.S. 252,265 (1977).

${ }^{166} \mathrm{Id}$. at 264-65. Discriminatory intent can be inferred from the circumstances surrounding the adoption of race-neutral legislation. See Davis, 426 U.S. at 242. As stated in Washington v. Davis,

Necessarily, an invidious discriminatory purpose may often be inferred from the totality of the relevant facts, including the fact, if it is true, that the law bears more heavily on one race than another. It is also not infrequently true that the discriminatory impact ... may for all practical purposes demonstrate unconstitutionality because in various circumstances the discrimination is very difficult to explain on nonracial grounds.

Id.

167 See Mt. Healthy City Sch. Dist. v. Doyle, 429 U.S. 274, 287 (1977). “Once racial discrimination is shown to have been a 'substantial' or 'motivating' factor behind enactment of the law, the burden shifts to the law's defenders to demonstrate that the law would have been enacted without this factor." Hunter v. Underwood, 471 U.S. 222, 228 (1985).

168 In Hunter v. Underwood, the Supreme Court approved the use of historical evidence to prove racial discrimination underlying legislation that "was part of a movement that swept the post-Reconstruction South to disenfranchise blacks." 471 U.S. at 228-29. The Court found sufficient evidence of intent to discriminate because of race in "the proceedings of the [constitutional] convention, several historical studies, and the testimony of two expert historians." Id. at 229. The Court concluded that "its original 
Interestingly, however, advocates who attempt to have Section 152(3) declared unconstitutional by a court will face problems proving discriminatory intent. First, there is no direct evidence of discriminatory intent in the legislative history of the NLRA. A second difficulty is posed by an intervening change in demographics: if the original intent was to injure blacks, then what difference does it make if Latinos, rather than blacks, are injured?

\section{Proof of Discriminatory Intent}

The current constitutional standards for proof of intent make proving the unconstitutionality of Section 152(3) difficult. The legislative history of the NLRA reveals no direct evidence of discriminatory intent. There is, however, strong circumstantial evidence from which one can infer discriminatory intent. The strongest evidence of discriminatory intent is the evidence provided by Leon Keyserling, whose recollections establish that the agricultural and domestic exclusion was adopted to ensure passage of the legislation. ${ }^{169}$ The evidence is strong, and pervasive throughout the period, that Southern Democrats would not support any New Deal legislation without this exclusion, a race-neutral proxy for the exclusion of most black employees. ${ }^{170}$

Additional evidence comes from Congress's failure to adopt a provision prohibiting unions from discriminating because of race. Because the legislative record contained the testimony of officials from the NAACP and the National Urban League documenting rampant union discrimination against blacks, we can assume that Congress was well-aware of the racism and consequent lack of union protection faced by black employees. ${ }^{171}$ Congress's failure to act to prevent racism is further evidence of its acquiescence in racism.

The overwhelming majority of historians and other scholars agree that, during the New Deal Era, the intention underlying agricultural and domestic worker exclusions was the racist intention to exclude most black employees

enactment was motivated by a desire to discriminate against blacks on account of race and the section continues to this day to have that effect. As such, it violates equal protection under Arlington Heights." Id. at 233. See also Arlington Heights, in which the Court described a "sensitive inquiry into such circumstantial and direct evidence of intent as may be available." 429 U.S. at 266 . This sensitive inquiry may include "the historical background of the decision ... particularly if it reveals a series of official actions taken for individious purposes." $I d$. at 267. The Court also approved consideration of the sequence of events leading to a challenged regulation and the legislative history of the regulation. Id. at 267-68.

169 See supra note 137-39 and accompanying text.

170 See supra notes $138-39,147-49$ and accompanying text.

171 See supra notes $141-44$ and accompanying text. 
from federal benefits and protections. ${ }^{172}$ This is the kind of expert historical evidence that the court found persuasive in proving discriminatory intent in Hunter v. Underwood. ${ }^{173}$ Historians' conclusions help establish that such exclusions were "part of a movement" to injure blacks and preserve their subordinated condition in the South. ${ }^{174}$ One can plausibly conclude, then, that racially discriminatory intent was a "motivating" or "substantial" factor underlying the enactment of the agricultural and domestic worker exclusion in the NLRA.

Unlike Hunter, however, where the legislative history of the challenged statute itself contained evidence of discriminatory intent, the legislative history of the NLRA contains no such evidence. To make the legal argument that the exclusion in the NLRA was discriminatory, one must "borrow" intention from the more easily proven discriminatory cases, such as the Social Security and Fair Labor Standards Acts. It is the context surrounding the NLRA, not the debates during its enactment, that proves the racism underlying Section 152(3).

The canons of statutory interpretation provide one argument that intention is properly inferable from context. Under the doctrine of in pari materia, a court may infer the meaning of a statutory provision from the meaning of related provisions enacted contemporaneously. ${ }^{175}$ As stated

172 See, e.g., FRYMER, supra note 1, at 27-28 ("The presence of Southern Democrats and their willingness to stray from the party line to block civil rights legislation not only prevented such legislation but necessitated that economic bills include provisions that either explicitly or, more often simply in a de facto manner, discriminated against large numbers of minority workers. The common method of this was for legislators to exclude categories of workers where African American and other minorities predominated, such as domestic and agricultural workers."); GOLUBOFF, supra note 1, at 29 ("Like many of the New Deal's economic protections, [the NLRA] excluded agricultural and domestic workers. Many of these workers were African American, so their exclusion marked a concession to southern white congressmen."); KATZNELSON, supra note 1, at 57-59; SITKOFF, supra note 1, at 52 ("Nor could Wagner do much to protect Afro-Americans from being excluded from the labor union movement. ... The civil rights groups pressing for the anti-discrimination amendment could not match the influence of those opposed to it.").

173471 U.S. at $228-29$.

174 Id. at 229.

175 Black's Law Dictionary defines in pari materia as follows:

1. adj. On the same subject; relating to the same matter. It is a canon of construction that statutes that are in pari materia may be construed together, so that inconsistencies in one statute may be resolved by looking at another statute on the same subject. "[I]t seems that the present position is that, when an earlier statute is in pari materia with a later one, it is simply part of its context to be considered by the judge in deciding whether the meaning of a provision in the later statute is plain." Rupert Cross, Statutory Interpretation 128 (1976). 
recently by the Supreme Court: "[W]e begin with the premise that when Congress uses the same language in two statutes having similar purposes, particularly when one is enacted shortly after the other, it is appropriate to presume that Congress intended that text to have the same meaning in both statutes."176 This presumption demonstrates the Court's willingness to borrow meaning across related statutes. The question before us, however, is slightly different: whether the intention underlying particular statutory language can be inferred to be the intention underlying similar language in a related statute.

The Court has used the legislative history underlying one statute to assist its construction of a different statute. In Smith v. City of Jackson, for example, the Court used the legislative history of Title VII to infer Congress's intent to provide a disparate impact cause of action in the related Age Discrimination in Employment Act. ${ }^{177}$ The Court is willing to use both the language and the legislative history of related statutes to discern the meaning of a statute. One can argue, therefore, that courts should use the context and intention of related New Deal statutes in understanding the intention underlying the agricultural and domestic worker exclusion in the NLRA.

Two New Deal Era statutes contain agricultural and domestic worker exclusions, the National Labor Relations Act and the Social Security Act. The Fair Labor Standards Act explicitly excluded agricultural workers. ${ }^{178}$ The NLRA, enacted July 5, 1935, ${ }^{179}$ and the SSA, enacted five weeks later on August 14, 1935, ${ }^{180}$ were contemporaneous, enacted at almost the same time during the same session of Congress. The FLSA was enacted three years later, on June $25,1938 .{ }^{181}$ Given the proximity of all of these enactments, it

2. $a d v$. Loosely, in conjunction with ... .

BLACK'S LAW DICTIONARY 862 (9th ed. 2009).

176 Smith v. City of Jackson, Miss., 544 U.S. 228, 233 (2005); see also Greenwood Trust Co. v. Mass., 971 F.2d 818, 827 (1st Cir. 1992) ("It is, after all, a general rule that when Congress borrows language from one statute and incorporates it into a second statute, the language of the two acts should be interpreted the same way."). The Court consistently applies this premise to language "derived in haec verba" from another statute. See Smith, 544 U.S. at 233-34.

177 Smith, 544 U.S. at 243.

178 The FLSA also excluded domestic workers but indirectly, through the requirement that employees be engaged in interstate commerce. KATZNELSON, supra note 1 , at 58 .

179 National Labor Relations Act, ch. 372, 49 Stat. 449 (1935) (codified as amended at 29 U.S.C. $\$ \S 151-169(2006))$.

180 Social Security Act of 1935, ch. 531, 49 Stat. 620 (codified in scattered sections of 42 U.S.C.).

181 Fair Labor Standards Act of 1938, ch. 676, 52 Stat. 1060 (codified as amended at 
is appropriate to consider their similar exclusions together.

The doctrine of in pari materia requires that we compare the statutory language to determine the propriety of commingled interpretation. ${ }^{182}$ The NLRA excludes from the definition of employee "any individual employed as an agricultural laborer, or in the domestic service of any family or person at his home ...."183 The SSA contains two exclusions-its old-age benefit provisions and its unemployment insurance provisions-both of which are identically phrased. ${ }^{184}$ The SSA excludes from its definition of employment "(1) Agricultural labor; (2) Domestic service in a private home ...."185 The FLSA, in pertinent part, excludes from its protections "any employee employed in agriculture ...."186

While the wording of the exclusions is not identical, it is very similar. Both the NLRA and the SSA refer to "agricultural labor" and "domestic service," rendering their exclusions quite comparable. The FLSA's agricultural exclusion appears broader. In addition, the FLSA contained additional language excluding employees engaged in the processing and production of products from agriculture. ${ }^{187}$ It is most probative that all three statutes - by providing either collective bargaining rights (NLRA), benefit payments (SSA), or minimum wages (FLSA)-threatened to equalize incomes, benefits, and working conditions between blacks and whites. As a concession to southern congressmen, the three statutes eliminated that threat by occupational exclusion of agricultural and domestic workers, an identified proxy for many black employees.

It seems reasonable to use the evidence of intention in surrounding statutes to understand the intention underlying the agricultural and domestic worker exclusion in the NLRA. This exclusion had the same effect in all the statutes-exclusion of most black employees from federal benefits and protections. In addition, the technique of occupational exclusion had been used prolifically in the antecedent NIRA also to exclude most blacks, strengthening the interpretation of this exclusion as racist in origin. ${ }^{188}$

It is clear that President Roosevelt wanted to enact New Deal legislation. It is clear that "[s]outherners controlled over half the committee

29 U.S.C $\S \S 201-219(2006))$.

182 See supra note 175.

183 National Labor Relations Act, ch. 372, § 2(3), 49 Stat. 449, 450 (1935) (codified as amended at 29 U.S.C. $\$ 152(3)$ (2006)).

184 Compare Social Security Act, ch. 531, §910(c), 49 Stat. 620, 625 (1935) with $\S 907(\mathrm{c}), 49$ Stat. at 643 . These are the identically worded provisions excluding agricultural and domestic labor.

185 Social Security Act $\$ 910(c)$.

186 Fair Labor Standards Act § 13(a)(6).

187 See Fair Labor Standards Act $\S 13(a)(10)$.

188 See supra notes 63-65 and accompanying text. 
chairmanships and a majority of leadership positions in every New Deal Congress." 189 It is also clear that Roosevelt would not sacrifice the passage of legislation for the sake of equality or fairness to blacks. The price of southern democratic support for New Deal legislation was the exclusion of most blacks and the consequent preservation of and support for Jim Crow. The exclusion of agricultural and domestic workers, a close proxy for most black workers in the South, stemmed from the racist southern desire to continue subordinating blacks. The historical evidence from the New Deal Era, together with the consistent exclusion of most black employees from New Deal benefits and protections, should be sufficient to support an inference of discriminatory intent underlying these exclusions.

\section{The Difference in Demographics}

Despite its race-neutral language, Section 152(3) continues to have a disproportionate impact. The race of the affected group, however, has changed. ${ }^{190}$ Although the provision originally excluded blacks from federal labor protections, today it excludes mostly Latinos. ${ }^{191}$ Today approximately $83 \%$ of agricultural laborers are Latinos. Clearly the provision has a disproportionate impact upon Latinos. ${ }^{192}$

One could argue that the difference between the originally injured group-overwhelmingly black-and the currently injured groupoverwhelmingly Latino-should defeat the argument that the statute still functions with racist intent. After all, I have demonstrated that Section 152(3) was intended primarily to deprive blacks of federal labor protections. The fact that today Latinos are disadvantaged by the statute may demonstrate that even if the original intent of the statute was racist, it can no longer be deemed so. Since, due to migration and occupational choice, ${ }^{193}$ blacks are no longer affected significantly by this statute, it should no longer be considered racist in the same way as the original enactment. Accordingly, the argument would run, its intent is not so clearly racist and therefore not so clearly

189 SITKOFF, supra note 1 , at 45.

190 I prefer to use the terminology of race when discussing Latinos, since I believe it to be a more powerful and evocative descriptor of the experience of U.S. Latinos, many of whom are racialized pervasively.

191 See supra notes 158-61 and accompanying text.

192 See supra note 160 and accompanying text.

193 On the role of mechanization on the great migration of blacks away from the rural South and toward urban centers in the North after 1940, see NICHOLAS LEMANN, The Promised Land: The Great Black Migration and How it Changed AmERICA 37 (1992). "Between 1910 and 1970, six and a half million black Americans moved from the South to the North; five million of them moved after 1940, during the time of the mechanization of cotton farming." Id. at 6. 
unconstitutional.

This argument, while interesting, is not persuasive. The doctrine of transferred intent exists both in tort law and criminal law. ${ }^{194}$ In criminal law, the doctrine of transferred intent provides that a criminal actor remains liable for a crime even if the victim is erroneous and unintended. ${ }^{195}$ Intent to murder does not disappear merely because, in the course of his murderous errand, the murderer kills someone other than the intended victim. ${ }^{196}$ The intention to kill being the same, and the effect being the same, a murder committed, the difference between the intended victim and the actual victim will not change, typically, the evaluation of intention to kill nor the evaluation of the crime nor its penalty. ${ }^{197}$ Murder remains murder.

The same principle of transferred intent should apply here. The consistency in the non-white character of the affected group and in the effect of the statute should argue strongly against constitutionality or legitimacy of any kind. The massive migration of blacks away from the rural South beginning around 1940 created a gap in agricultural labor filled by Latino, mostly Mexican, farm laborers. ${ }^{198}$ I have shown that the original intention

194 See Vincent R. Johnson, Transferred Intent in American Tort Law, 87 MARQ. L. REV. 903, 909-10 (2004) (criticizing reliance on transferred intent in tort law because recovery possible under contemporary principles of comparative negligence).

195 See MODEL PENAL CODE $§ 2.03$ (2) (1985), which provides:

When purposely or knowingly causing a particular result is an element of an offense, the element is not established if the actual result is not within the purpose or the contemplation of the actor unless:

(a) the actual result differs from that designed or contemplated, as the case may be, only in the respect that a different person or different property is injured or affected or that the injury or harm designed or contemplated would have been more serious or more extensive than that caused; or

(b) the actual result involves the same kind of injury or harm as that designed or contemplated and is not too remote or accidental in its occurrence to have a [just] bearing on the actor's liability or on the gravity of his offense.

196 See id.

197 See Anthony M. Dillof, Transferred Intent: An Inquiry into the Nature of Criminal Culpability, 1 BUFF. CRIM. L. REV. 501, 502 (1998) ("Pursuant to the doctrine of transferred intent, $A$ 's intent to harm $B$ is treated as the intent to harm $C$, with liability to follow accordingly."). I note that the doctrine of transferred intent is controversial and has been criticized on the grounds that unintended results are not morally equivalent to intended results. See id. at 502-03; see also Kimberly Kessler Ferzan, Beyond Intention, 29 CARDOZO L. REV. 1147, 1150-52 (2008).

198 See LEMANN, supra note 193, at 6. The cyclical use and exploitation of Mexican farm labor during times of labor shortage has a long, well-chronicled history in the United States. See, e.g., Gilbert Paul Carrasco, Latinos in the United States: Invitation and Exile, in IMMIGRANTS OUT! THE NEW NATIVISM AND THE ANTI-IMMIGRANT IMPULSE IN THE UNITED STATES 190 (Juan F. Perea ed., 1997). 
underlying the exclusion was to preserve the economic deprivation of most black farm laborers and to preserve the South's racial caste system. These intentions were accomplished against blacks when the statute was enacted, and the effects continue to be the same today with respect to Latinos. As a result of Section 152(3), Latino farm and domestic workers languish in shocking poverty, powerless to improve their economic condition and influence through collective action. Given that Section 152(3) reproduces the same debilitating effects upon Latinos as upon blacks in an earlier era, the statute should be held unconstitutional or repealed.

\section{B. The Repeal Strategy}

Given the potential proof problems in a litigation strategy, it is important to ensure that the racism inherent in Section 152(3) is not perpetuated. Accordingly, the most productive strategy is probably a legislative strategy of repeal. The most important reason to repeal Section 152(3) is to end the racially-identified harm the statute produces and to provide fairness, for the first time, to farm and domestic workers. It is unconscionable that the least powerful, most exploited workers in the economy lack the basic right to unionize and to attempt to improve their working conditions and bargaining position. It is unconscionable that the weakest lack rights made available to industrial workers already wealthier, more powerful and better able to protect themselves. We should not be in the business of retaining unconscionable laws. We should fulfill Senator Wagner's original, inclusive vision of collective bargaining rights available to all. 199

Upon entering office, legislators swear an oath to support and defend the Constitution. ${ }^{200}$ It would seem, then, that as a simple matter of supporting the Constitution and its promise of equal protection, members of the House and Senate have a duty to repeal laws that discriminate based on race. Given the genesis of the agricultural and domestic worker exception, there is no interpretation of equal protection that can save a statute intended to preserve the subordinate status of black sharecroppers and domestics by denying them

199 See supra notes 138,145 and accompanying text.

200 The legislator's oath is as follows:

I, [name], do solemnly swear (or affirm) that I will support and defend the Constitution of the United States against all enemies, foreign and domestic; that I will bear true faith and allegiance to the same; that I take this obligation freely, without any mental reservation or purpose of evasion; and that I will well and faithfully discharge the duties of the office on which I am about to enter. So help me God.

5 U.S.C. $\S 3331$ (2006). See generally Vic Snyder, You've Taken an Oath to Support the Constitution, Now What? The Constitutional Requirement for a Congressional Oath of Office, 23 U. ARK. LITTLE ROCK L. REV. 897 (2001). 
payments and benefits freely given to mostly white industrial workers. The fact that the law remains effective, continuing to damage millions of Americans, strengthens the legislative obligation to support the Constitution by repealing this racist, discriminatory law. 201

Although several legitimate, race-neutral reasons could be offered to sustain Section 152(3) today, none of these would be good reasons. One could argue, for example, the administrative inconvenience and difficulty that would result from attempts to organize farm workers or domestics. ${ }^{202}$ Or, as voiced during hearings on the NLRA, one might be concerned about the effects of potential unionization on small family farms. ${ }^{203}$ Another concern might arise from the reliance of agricultural producers on the existing structure of the market for agricultural labor.

The fact that we can imagine some plausible, legitimate reasons to enact the same statute today should not protect the statute from repeal. Arguments about the administrative difficulty of organizing agricultural or domestic workers ring hollow. To the extent that these are problems, they would be problems for unions or the workers themselves, not for the entities likely to oppose invalidation of the provision. If the burden of unionization is greater than the benefits for unions or workers, then they will not engage in it over the long run. The potential difficulty of exercising a right should not trump the availability or the existence of the right itself. Whatever problems might exist, they have been successfully surmounted in California, which has long allowed unionization and collective bargaining for agricultural workers. ${ }^{204}$

While concerns over the effects of unionization on small farms might be legitimate, it remains telling that Congress never imposed a size limitation on employers subject to the NLRA. ${ }^{205}$ It seems hard to imagine a good reason for exempting only small farms and employers of domestics when other similarly situated small employers enjoy no such exemption from potential

201 I am grateful to John Nowak for his comments and for this apt constitutional argument.

202 This argument was made in support of excluding agricultural and domestic workers from the Social Security Act. See Davies \& Derthick, supra note 127, at 226.

203 See supra notes 121-26 and accompanying text.

204 California's labor code provides the following:

Employees shall have the right to self-organization, to form, join, or assist labor organizations, to bargain collectively through representatives of their own choosing, and to engage in other concerted activities for the purpose of collective bargaining or other mutual aid or protection, and shall also have the right to refrain from any or all of such activities except to the extent that such right may be affected by an agreement requiring membership in a labor organization as a condition of continued employment as authorized in subdivision (c) of Section 1153.

Cal. Labor Code $\S 1152$ (West 2003). 205 See 29 U.S.C. § 152(2) (2006). 
unionization.

Any reliance argument made by employers of agricultural and domestic laborers should be examined with great skepticism. As we have seen, the agricultural and domestic worker exclusion was created to deprive blacks of old age pensions, unemployment insurance, fair and equal wages, and bargaining power. ${ }^{206}$ The exclusion was intended to, and did, preserve the ability of white southern agricultural landowners to exploit and subordinate economically their black employees. Contemporary reliance on equally exploitive and subordinating laws is really not a race-neutral argument at all. It is an argument for continued exploitation, subordination, and transfer of wealth from the most vulnerable workers to those who profit from their exploitation. Reliance on exploitation is not a legitimate argument for continued exploitation.

Ostensibly race-neutral words should no longer hide palpably racist actions. The failure to repeal Section 152(3) today becomes this generation's tacit acquiescence in continuing slavery and peonage.

\section{CONCLUSION}

It is shocking that Section 152(3), a vestige of New Deal racism, remains law and continues to inflict racially-identified harm. It remains on the books due to indifference to the welfare of farm and domestic workers. It remains on the books because of a telling lapse in historical memory, which constructs the New Deal as a time of government-engineered recovery and rights for all Americans, when in fact black Americans were excluded from most of its benefits. Given the racist origins of the exclusion, the burden of justifying the preservation of the statute should lie with its proponents. ${ }^{207}$

Nonetheless, its continued existence and operation teach important lessons. First, occupational exclusion from federal protections is a remarkably effective way to create and preserve racial caste. Second, raceneutral language has been and can be used purposefully to inflict raciallytargeted harm upon politically vulnerable groups. It is only our temporal distance from the crafting of this exclusion that even permits us to deem it "race-neutral." Its authors, as well as those most affected by the exclusion, knew it to be anything but neutral.

Another lesson lies in the overly difficult hurdles posed by current constitutional standards for the proof of discriminatory intent. The rule of Washington $v$. Davis and its progeny creates the offensive possibility that an

206 See supra Section II.

207 Cf. Hunter v. Underwood, 471 U.S. 222, 228 (1985) ("Once racial discrimination is shown to have been a 'substantial' or 'motivating' factor behind enactment of the law, the burden shifts to the law's defenders to demonstrate that the law would have been enacted without this factor."). 
[Vol. 72:1

obviously racist law could nonetheless be found consistent with the Constitution. The possibility of such an outcome breaks the promise of governmental even-handedness that underlies the Equal Protection Clause.

It is past time to amend the labor laws and to purge this vestige of New Deal racism from that which we respect as law. 